\title{
Pharmaceutical Industry in China: Policy, Market and IP
}

\author{
Xiangdong Chen, Shaofang Xue, Miaochen Lv, \\ and Ruolan Wang
}

\begin{abstract}
This chapter provides a three-prong investigation framework on Chinese pharmaceutical industry, namely, policy structure, market structure and IP (patentbased) structure. The Chinese pharmaceutical industry has been developing fast in market size and revenue volumes. However, the scale of Chinese pharmaceutical companies is relatively small, and the market concentration is low. Therefore, local pharmaceutical companies with higher R\&D input are generally less profitable. Although there is increase in the number of patented drugs in the pharmaceutical industry in China, patents have made relatively low contribution to the industrial values, and IP held by Chinese firms is less competitive compared with that of foreign companies. Most of the pharmaceutical enterprises in China still focus on generic drugs. Market regulation of the pharmaceutical industry in China is relatively strict, especially market entry and price control. A detailed comparison between Chinese and Indian industry is given by this chapter.
\end{abstract}

\section{Keywords}

Pharmaceutical industry · Intellectual property $\cdot$ IP $\cdot$ Patented drugs $\cdot$ Generic drugs $\cdot$ China $\cdot$ India

X. Chen $(\triangle) \cdot$ S. Xue $\cdot$ M. Lv $\cdot$ R. Wang

School of Economics and Management, Beihang University, Beijing,

People's Republic of China

e-mail: chenxdng@buaa.edu.cn 


\section{$1 \quad$ Approaches and Framework}

The best way to understand the development of pharmaceutical industry and its ancillary industries in China is by analyzing the literature authored by the Chinese scholars and gaining insights into major research topics and findings. The data analyzed in this chapter is derived from about 60 research articles, publicly released information and $\mathrm{PhD}$ theses in Chinese academic journals and literature databases. We provide a three-prong investigation framework on Chinese pharmaceutical industry, namely, policy structure, market structure and intellectual property (IP) (patent-based) structure in the industries.

Prong 1 deals with government policy framework or structure for pharmaceutical industries in China, primarily market entry policy, pricing policy, monitoring and regulation policies, which may bring positive and negative influence on industrial development. Prong 2 deals with market structure of Chinese pharmaceutical industries, primarily competition and monopolistic characters, driven by multiple influencing factors. Prong 3 focuses particularly on IP (patents) resource structure in Chinese pharmaceutical industries and market.

This three-prong investigation framework is much relevant in the Chinese context, since Chinese economies have been continually developed by policy and market, where foreign investment and multinational enterprises are especially significant in pharmaceutical industry. Moreover, IP and patents in Chinese market are crucial, as in any other countries, especially emerging economies. R\&D and patent resources often prove to be key for market competition.

This chapter first starts with an overview of China's pharmaceutical industry, which covers both historical development and current market characters, especially problems, in pharmaceutical industries. It then proceeds to examine the policy structure, market structure and IP (patent-based) structure in the industries. The findings about Chinese market will be compared and contrasted with Indian ones on a number of important issues before this chapter ends with a conclusion.

\section{Overview of China's Pharmaceutical Industry}

\subsection{The Historical Development}

The historical development of pharmaceutical industry in China from 1949 onwards can be summarized as below (see Table 1).

\subsection{Current Status}

\subsubsection{Expansion of Total Industrial Scale}

According to the China Statistical Yearbook, the output of China's pharmaceutical industry has been increasing year by year, from RMB 137.27 billion in 1998 to RMB 944.33 billion in 2009. Although the proportion of pharmaceutical 
Table 1 The historical development of China's pharmaceutical industry (Wang 2013)

\begin{tabular}{|c|c|c|}
\hline Phase & Period & Description \\
\hline Founding & $\begin{array}{l}1949- \\
1978\end{array}$ & $\begin{array}{l}\text { With primitive and unproductive facilities, chemical } \\
\text { pharmaceutical industries mainly imported raw materials and then } \\
\text { processed them into simple preparations. In 1950, China could } \\
\text { only produce several tons of active pharmaceutical ingredients } \\
(\text { APIs }) \text {. The first 5-year plan stated that "The pharmaceutical } \\
\text { industry will focus on the development of APIs". In light of } \\
\text { endemic and infectious diseases, the strategies adopted by China } \\
\text { combined self-development with introduction from the Soviet } \\
\text { Union, focusing on the development of anti-infective drugs, } \\
\text { antipyretics, analgesics, vitamins and so on. Unfortunately, in the } \\
\text { 1960s and 1970s, a chaotic situation developed under the influence } \\
\text { of "Leftism", where pharmaceutical factories were managed in a } \\
\text { disorderly manner and drugs were produced indiscriminately. In } \\
\text { the early 1970s, DNA recombination technology began to be } \\
\text { applied to medicine, showing a big gap with developed countries } \\
\text { (Sun 2016) }\end{array}$ \\
\hline Developmental & $\begin{array}{l}1978 \\
\text { on } \\
\text { wards }\end{array}$ & $\begin{array}{l}\text { At the beginning of opening up policy implementation, the State } \\
\text { Pharmaceutical Administration was established, under which four } \\
\text { state-owned pharmaceutical companies were set up to encourage } \\
\text { medical institutions to generate profits. Thus, the number of } \\
\text { pharmaceutical manufacturers increased rapidly, from } 1000 \text { in } \\
1985 \text { to } 6300 \text { in } 1995 \text {. However, most pharmaceutical companies } \\
\text { operated on a small scale, facing ubiquitous and cut-throat } \\
\text { competition. In 1998, the State Food and Drug Administration was } \\
\text { established to gradually regulate the development of the China's } \\
\text { pharmaceutical industry, enforce Good Manufacturing Practice } \\
\text { (GMP) and control the creation of new pharmaceutical companies. } \\
\text { After the year 2000, with the influx of multinational and private } \\
\text { enterprises, mergers and acquisitions in the pharmaceutical } \\
\text { industry increased. In 2011, the number of pharma companies in } \\
\text { China increased to 5674, with total turnover of RMB } 1.53 \text { trillion } \\
\text { (or about US\$243 billion in price), among which } 2110 \text { were } \\
\text { chemical pharma companies, with revenue of RMB } 0.72 \text { trillion. } \\
\text { The market concentration level was low (share of top } 10 \text { pharma } \\
\text { companies accounted only } 15-18 \% \text { of the market), which indicates } \\
\text { larger proportion of medium and smaller companies }\end{array}$ \\
\hline
\end{tabular}

${ }^{\mathrm{a}} \mathrm{APIs}$ are pharmaceutical raw materials, according to $\mathrm{CHI}$ (International Conference on Harmonization of Technical Requirements for Registration of Pharmaceuticals for Human Use) Q7A, APIs are any substance or material that can be used in pharmaceutical manufacturing, provided that the substance can be one of active composition, being pharmacologically effective in diagnostic procedure, medical treatment, and symptom release of certain disease, or influential to function or structure of human body

manufacturing industry in overall GDP dropped slightly in 2004, the industry was still showing a minor growth, from $1.63 \%$ in 1998 to $2.77 \%$ in 2009 (Liu 2012). Meanwhile, it had been also showing significant increase from 2006 to 2010, the average annual growth rate of China's pharmaceutical industry amounted to $23.9 \%$, the fastest growing in the world. In 2010 alone, China's pharmaceutical industry achieved sales of US\$ 41.1 billion, making it the third largest sales worldwide (IMS 2015). 
Sales revenue/ 0.1 billion yuan

Year on year growth rate $/ \%$

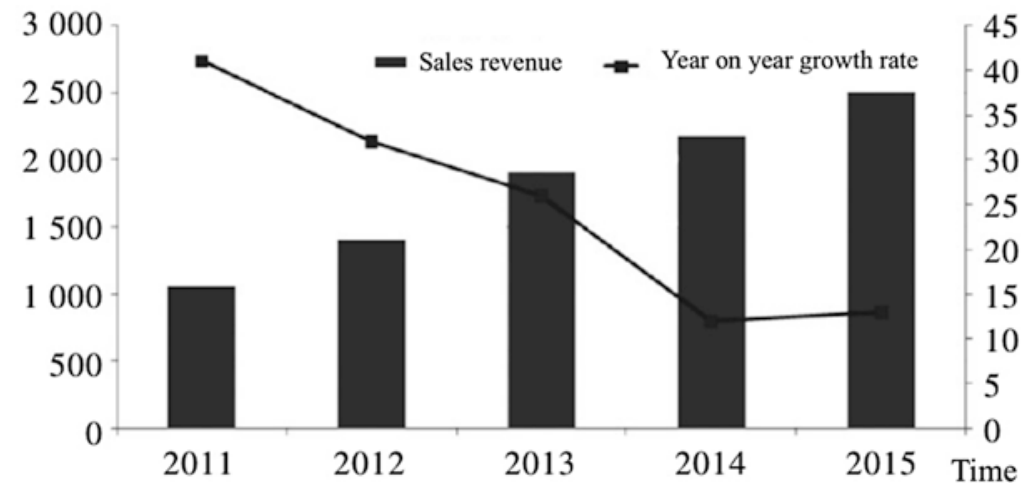

Fig. 1 China's biopharmaceutical manufacturing sales revenue (2011-2015) (Li and Yang 2016)

In 2016, the business income of large-scale industrial enterprises ${ }^{1}$ in China's pharmaceutical industry reached RMB 2.96 trillion, an increase of $9.92 \%$ over the previous year. In the first quarter of 2017, the revenue of the listed companies in the pharmaceutical industry increased by $14.64 \%$, an increase of $0.04 \%$ over the same period of the previous year (Chen and Wang 2017).

In the field of biopharmaceuticals, the domestic sales revenue was at a relatively high level, but the growth rate slowed down. In 2013, the gross industrial output value reached RMB 229 billion, an increase of $24.24 \%$ over the previous year; and the annual value of industrial sales reached RMB 128.6 billion, up by $17.12 \%$. As shown in Figs. 1 and 2, in 2015, China's biopharmaceutical manufacturing revenue from product sales was RMB 186.4 billion, and the total profit was RMB 31.0 billion, up $14.8 \%$ and $21.6 \%$, respectively, over the previous year.

According to Zhang (2009), who applied the C-D Production Function and Solow/Romer's model on empirical investigation over industrial competitive advantages in Chinese medicine manufacturing sectors, the industry was still on production factor-oriented session, which revealed that technological innovation was one of the key factors in upgrading pharmaceutical industries in China.

\subsubsection{Improvement in Industrial Capacity}

In terms of industrial capacities, the production of Chinese pharmaceutical companies covers APIs, intermediates, preparations, pharmaceutical excipients, pharmaceutical packaging and pharmaceutical machinery. Among them, about 1300 kinds of chemical APIs and more than 4500 kinds of preparations were manufactured.

\footnotetext{
${ }^{1}$ According to National Economic Industrial Classification, 2017, GB/T 4754-2017, larger-sized industrial enterprises are classified based on two basic conditions: annual turnover larger than RMB 400 million and staff number more than 1000. As an example, the tenth largest pharmaceutical companies in China in 2016, Ha Yao Manufacturing Group, achieved annual revenue of RMB 12 billion, with 407 million net profit and 198 million R\&D investment, supported by 17,895 staff (http://www.hayao.com).
} 
Total profit/ 0.1 billion yuan

Year on year growth rate $/ \%$

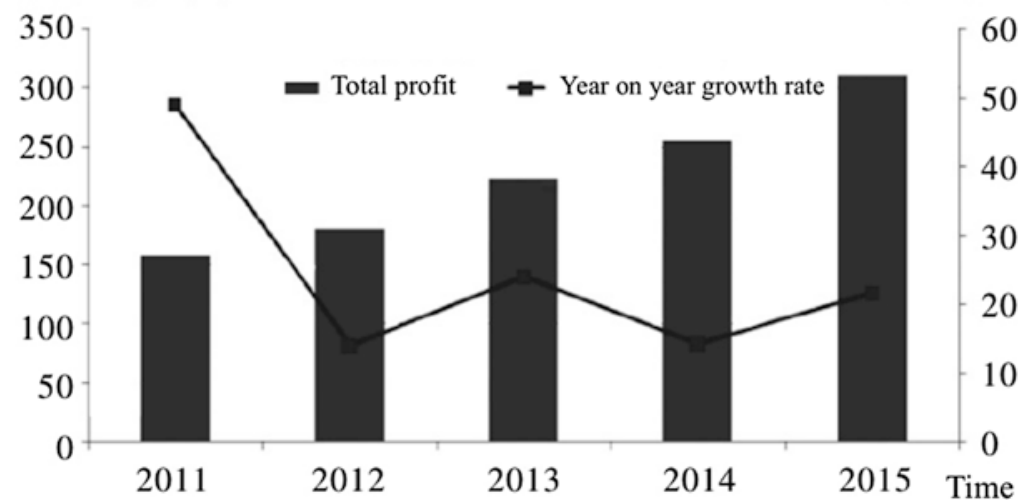

Fig. 2 China's biopharmaceutical manufacturing total profit (2011-2015) (Li and Yang 2016)

The output of chemical APIs reached 430,000 tons in 1999, of which 260,000 tons were APIs in 24 major categories. China became the second largest producer of APIs in the world. Its penicillin and P-Lactam drugs and vitamins accounted for $30 \%$ of the world's total output, making China the world's largest producer and exporter with 205.07 million tons in 2007. In biological pharmacy, China currently produces more than 300 kinds of biological products such as vaccines, toxoids, blood products and diagnostic reagents in vitro and in vivo (Liu 2012). According to recent website information, both domestic market and export market increased despite 2009 world financial crises. The trade volume in pharmaceutical and health product in China in 2017 was US\$116.76 billion, increased 12.64\% year-on-year, among which US\$60.8 billion export, the highest growth within a 5-year interval, and US\$55.88 billion import, with a growth rate of $16.34 \%$, and US\$4.9 billion trade surplus, a $34.60 \%$ drop compared with previous year (Sohu website 2018). The domestic market increase might be related to medical service reform since 2009, when RMB850 billion has been invested by government on medical social welfare system.

\subsubsection{High Degree of Market Opening Up, Strong Market Shares by Foreign-Funded Enterprises}

Another notable feature of China's pharmaceutical industry is its opening up to the world. According to Mu and Cai (2001), both openness and innovative capacity were basically lower than overseas companies in 2000, if measured by four-dimension models (competitiveness, competitive potentiality, competitive environment and competitive position). However, the industry has been opened up since then.

At present, the top 20 multinational pharmaceutical companies in the world have all set up joint ventures, which are transforming into holding or wholly owned business models that occupy the key regional and high-end product markets in China. There are more than 1800 joint pharmaceutical enterprises and dozens of imported pharmaceutical enterprises in China, and they account for about one third 
of China's chemical market. Among the top 50 best-selling drugs on the market in China, imported drugs and joint-stock drugs account for 40 species (Wang 2008).

Multinational pharmaceutical companies have large-scale deployment of R\&D centres in China, such as AstraZeneca, Eli Lilly, GlaxoSmithKline and Roche (Liu 2012).

As for opening to the world, in June 2008, the Academy of Military Medical Sciences and Phytopharm, a British company in plant medicine, signed a cooperation agreement on "NJS" (a new type of Chinese medicine) with "patent licensing", marking the first time that a Chinese patent for innovation in traditional Chinese medicine went abroad. This is also the first time that China has authorized the use of IP of Chinese medicine by international companies (Liu 2012).

\subsubsection{Administration of Pharmaceutical Industries in China}

Currently, the administrative oversight over pharmaceutical manufacturing industries in China involves government agencies in vertical as well as horizontal relationship, which includes National Food \& Medicine Monitoring and Administration Bureau and its local sublevel branches in different regions, State Family Planning Commission, National Development and Reform Commission and Ministry of Human Resource and Social Welfare. There are responsible departments and sections within the above-mentioned government organizations.

\subsection{Problems in the Development of China's Pharmaceutical Industry}

\subsubsection{Low R\&D Investment in Pharmaceutical Companies}

There are some advantages for drug R\&D in China. For example, R\&D investment in the chemical pharmaceutical industry is relatively low, and the cost of experimental and clinical studies on animals is only about $20 \%$ and $10 \%$, respectively, of the cost in developed countries (Liu and Wang 2007). According to the IMS Pharmaceutical Industry Data Report, in 2007 the R\&D intensity ${ }^{2}$ in China was $1.77 \%$ on average, while the R\&D intensity of top 10 pharmaceutical companies in the United States was $35.3 \%$ (IMS 2008), which may imply that Chinese pharmaceutical companies are more focusing on close-to-current-market operations, rather than longer-term drug development for future market.

According to the data of "pharmaceutical managers" in the United States in 2015 , the top 50 global pharmaceutical companies invested $10 \%$ or more on R\&D against their total turnover (William 2016). According to statistics from China Pharmaceutical Industry Information Centre, in 2015 only three of the top 100 China's pharmaceutical enterprises invested more than $10 \%$ in R\&D.

There are three main sources of R\&D funding: government, enterprises and financial institutions. By far, number 1 source is self-financing (see Fig. 3).

\footnotetext{
${ }^{2}$ The $R \& D$ intensity means the ratio of $R \& D$ investment over their production value by pharmaceutical enterprises.
} 


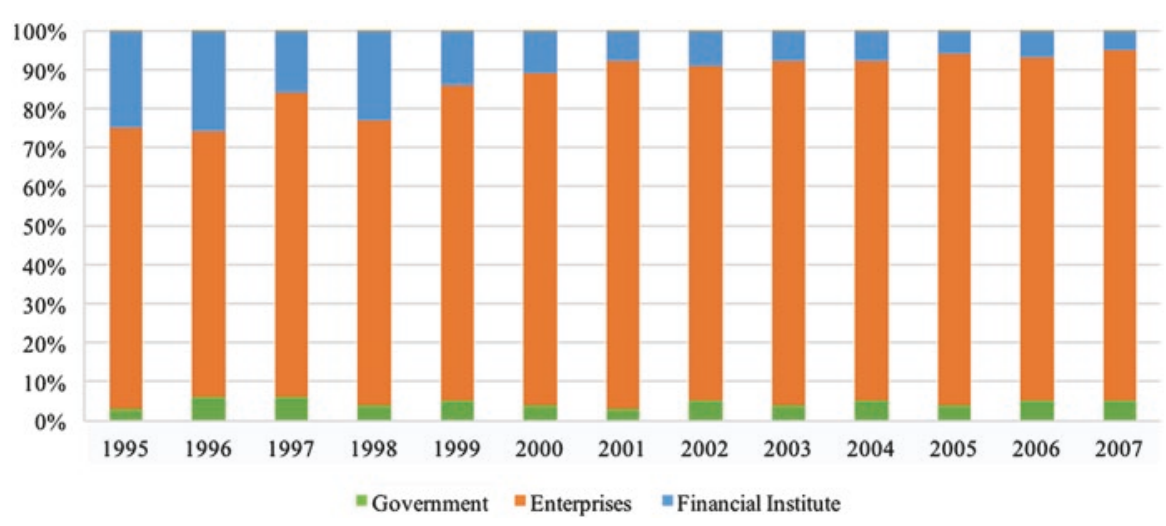

Fig. 3 Proportion of R\&D sources for pharmaceutical enterprises in China (1995-2007) (Liu 2012)

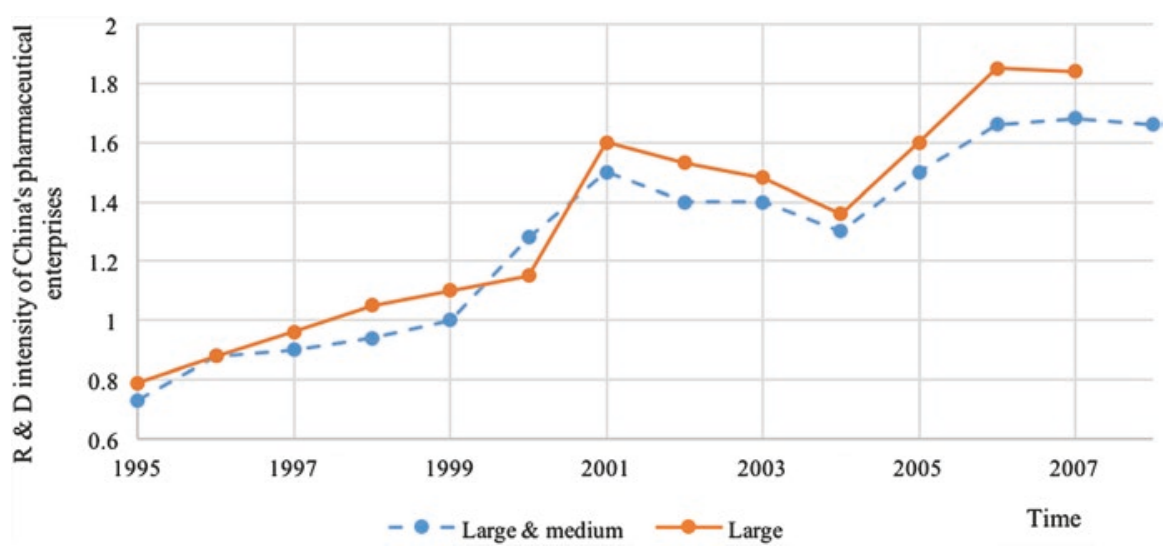

Fig. 4 R\&D intensity of China’s pharmaceutical companies (1995-2007) (Liu 2012)

In the past 10 years, China's pharmaceutical companies have gradually increased their R\&D intensity. Although some pharmaceutical companies have paid great expenditure on $\mathrm{R} \& \mathrm{D}$, the $\mathrm{R} \& \mathrm{D}$ level is still relatively low compared to international companies (see Fig. 4)

In terms of full-time R \& D personnel in China's pharmaceutical industry, it is almost in line with the overall change in the pharmaceutical industry (see Fig. 5). Generally speaking, R\&D efficiency in pharmaceutical industries in China is still low. ${ }^{3}$

\footnotetext{
${ }^{3}$ According to Ji and Zhou (2010), the overall R\&D efficiency slightly declined between 1997 and 2008, with quite significant fluctuations based on the empirical examination via non-HMB Productivity Index (or Malmquist Index). Another study, via a stochastic frontier production function method by Zhang et al. (2011), proved that the overall R\&D efficiency in Chinese pharmaceutical industries was lower, although with a positively graduate growth, based on an examination of impact from government investment, technology reformation expenditure, company size and market structure.
} 


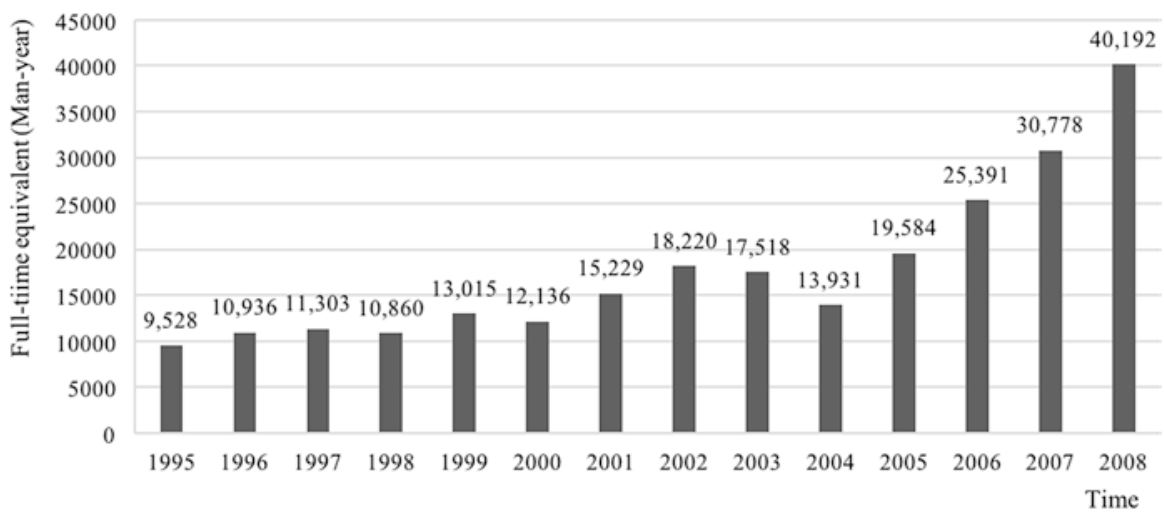

Fig. 5 Full-time R\&D personnel in China's pharmaceutical enterprises (1995-2008) (Liu 2012)

\subsubsection{Vehicle for New Drugs R\&D Is Research Institutions, Not Enterprises}

At present, China's main vehicle for new drugs R\&D is still research institutions, not enterprises (Liu 2012), through the following approaches:

1. Research institutions and pharmaceutical companies jointly declare new drugs after achieving results in a mode where pharmaceutical companies funded study by the research institutions.

2. The development of new drugs is completed by the research institutes, then transferred to pharmaceutical companies after the new drug eligibility approval.

3. Research institutions have their own pharmaceutical manufacturers to produce the new drugs they developed.

Accordingly, the legal owners of pharmaceutical patents are mostly research institutes and small high-tech businesses.

\subsubsection{Lack of Advanced Technology and IP Rights by Chinese Pharmaceutical Companies}

Among the pharmaceutical products currently manufactured in China, less than $3 \%$ have IP rights. More than $97 \%$ of the domestically produced drugs are generic drugs (Yu 2008). At present, there are mainly two types of generic drugs produced in China: one that imitates drugs patented by foreign enterprises and have expired or are about to expire and another that imitates listed drugs by domestic enterprises. Even imitating others' drugs, most pharmaceutical companies in China mainly focus on producing generic drugs with relatively lower technical requirements and mature technologies and involve less high-tech and high value-added pharmaceutical products. Often there are some 70-80 enterprises producing the same drug in China (Liu 2012). 
By September 2006, there were 1172 enterprises producing compound sulfamethoxazole files, 1049 enterprises producing analgene, 1049 enterprises producing vitamin C (Wei 2009) and more than 300 enterprises producing amoxicillin in China. This means serious overcapacity of China's pharmaceutical industry. The utilization rate of production capacity of tablets, capsules, powder injection and water injection were less than 45\%,40\%, 27\% and 50\%, respectively (Wu 2006).

\subsubsection{Small-Scale Pharma Companies, Low Market Concentration and Substantial Percentage of Enterprises in Deficit}

According to China Statistical Yearbook, from 1995 to 2008, the share of smallscale enterprises in the pharmaceutical industry in China was high at 70-80\%. By 2008, there were 6524 pharmaceutical companies in China. Only 1003 are mediumand large-scale enterprises and the rest small businesses. By 2009, there were 6807 pharmaceutical companies in China, of which 5787 were small- and medium-scale enterprises (Liu 2012). In 2004, China's pharmaceutical industry concentration ratio of the ten biggest companies (CR10) was $15.10 \%$, while the world pharmaceutical industry CR10 had reached 55\% (Jin et al. 2007). In 2008, the top 100 enterprises in the pharmaceutical industry achieved a total sales revenue of RMB 246.937 billion, accounting for only $40.59 \%$ of the total sales of the industry (Cai 2009).

Pharmaceutical companies have lower economies of scale and larger losses. According to the "Statistical Yearbook of China's Industrial Economy", from 1999 to 2009, among China's pharmaceutical enterprises, the number of loss-making enterprises ranged from 739 to 1248 , accounting for about $18.3 \%$. Overall, from 1999 to 2007, the proportion of loss-making enterprises in all pharmaceutical enterprises in China was 20\%-26\%, $18 \%$ in 2008 and 15\% in 2009 (Liu 2012).

\subsubsection{Increasing but Low Export of Traditional Chinese Medicine}

Traditional Chinese medicine is the most advantageous pharmaceutical field in China and has developed greatly over the years. However, due to lack of innovation, larger market shares are still held by Liuwei Dihuang Wan and other traditional Chinese medicines (Liu 2012).

In 2012, there were more than 1500 traditional Chinese medicine manufacturers in China, with 2772 products and 6310 varieties and specifications, total sales of which amounted to RMB 60 billion. The development of traditional Chinese medicine in different disease treatments is not balanced, accounting for more than $30 \%$ in therapeutic areas like cardiovascular, urinary, respiratory and skeletal muscle systems.

However, compared to the sales in the domestic market, the export value of traditional Chinese medicine is relatively low, and its share in the international market has not been high. It is reported that in 2012, the export of traditional Chinese medicine products from China was only US\$2.499 billion, of which Chinese herbal medicines US 265 million, extracts US1.164 billion, in total with US\$ 3 million deficit. 


\section{Policy Structure of China's Pharmaceutical Industry}

Unlike the genetically modified food discussed in chapter "Genetically Modified Foods in China: Regulation, Deregulation or Governance?", there are relatively detailed legislation in China's pharmaceutical industry. On the whole, the pharmaceutical industry policy in China mainly involves two aspects: First, the management of the pharmaceutical market, including market access and approval of drugs. Second, the macro-management of the pharmaceutical industry, including drug pricing policy, drug regulatory policies on industrial structure and layout policy, drug procurement policies and even medical science and technology policy. This section will only deal with the issues of market access and approval of drugs, drug pricing policy and regulatory policies on industrial structure and layout.

\subsection{The Access to Drug Market and Approval of Drugs}

\subsubsection{Approval of New Drugs}

The access to pharmaceutical market reflects the regulatory requirements of the pharmaceutical industry, particularly for new drug products, which mainly include the registration and administrative approval of new drugs and technical review requirements. According to Chen (2014), such market entry starts from the initial research stage and goes through seven phases in total:

1. The discovery and screening phase of new drugs: Pharmaceutical companies will first identify a new composition with certain pharmacological properties and then select the best compound to be used as a new chemical entity (NCEs) during ongoing optimizations.

2. Preclinical research phase: research drug synthesis, which generally studies the extraction method, purity, dose, pharmacology, toxicology, etc.

3. Clinical trial phase: start to form a regular procedure.

4. The enterprise shall fill in The Application Form for Drug Registration and submit the relevant information to the drug regulatory department of the province, autonomous region or municipality.

5. The State Food and Drug Administration will make the examination and approval decision. Those enterprises in line with the provisions will be issued Drug Clinical Trial Approval Document, those not in line with the requirements will be issued Notice of Trial Opinion and explained the reasons.

6. Drug Clinical Trials (Including Bioequivalence Trials): This process requires the implementation of Quality Management Specifications for Drug Clinical Trials. Clinical trials are divided into I, II, III and IV. After the approval, the clinical trial must be implemented within 3 years; otherwise the original approval documents shall be abolished. For the applications of overseas pharmaceutical companies, the drugs must have entered phase II or phase III clinical trials.

7. Applying for the production and sale of new drugs: the drug approval number shall be issued after the technical review by the drug administration department 
so as to obtain the legal qualification for the production of the new drug. Even after the approval of new drugs, the national drug administration needs to monitor safety of the drugs, but not for more than 5 years.

For new chemical drugs, it takes approximately 17-18 months to get the clinical permit after the application. Even if the new drug is listed, it also has to face market access problems and must go through the provincial access (drug bidding) and hospital access. The process depicted in Fig. 6 shows that the average bidding period of 31 provinces and autonomous regions in China is 14 months. After winning the bid, the drug should be purchased by the hospital. If it needs to become a new drug which can be reimbursed, entering the national and provincial health insurance directory is necessary. Overall, it takes at least 3 years for new drugs to be listed in China (Chen 2014).

As a whole, the current system of examination and approval of new drugs has unclear and overbroad regulations. Meanwhile, the lack of related professionals and the lengthy process of approving new drugs have resulted in loss of revenue for innovative pharmaceutical products (Chen and Wang 2017).

\subsubsection{The Generic Drug Application Procedure and Its Incentive System}

The process of approving generic drugs in China is similar to the approval of new drugs, which takes about 3 years (Chen 2014) (Fig. 7).

Due to lengthy and complex processes, current market access mechanism also lacks incentives for the development of generic drugs.

\subsection{Drug Pricing Policies}

Regulations particularly on pricing in the industries are summarized in Table 2.

After thorough development of pricing policies in pharmaceutical industries for so many years, the current pricing system in the industry can be summarized in Table 3.

In 2011, the cost of purchasing drugs by residents accounted for $50 \%-62 \%$ of the total health expenditure in China, much higher than the world average of 20\%-30\% (Yao 2011). At present, there are three ways of pricing the drug market in China: (Liu 2012).

\section{A. Government-guided pricing}

Drugs included in the Catalogue of National Basic Medical Insurance shall be priced in the following ways: the central government is responsible for setting prescription drug prices, and local governments set the prices of over-the-counter medicines. 


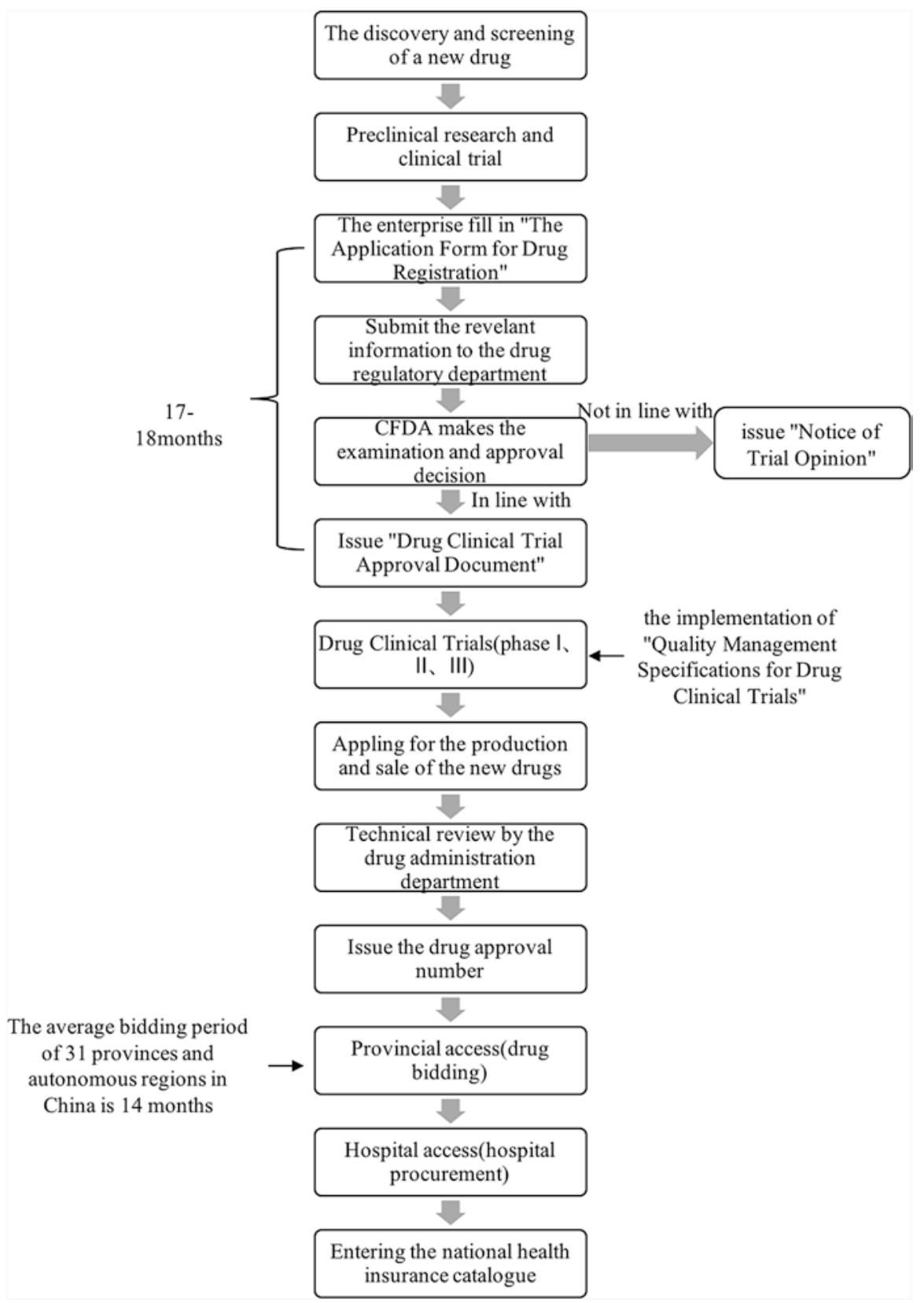

Fig. 6 Flow chart of new drug listing in China 


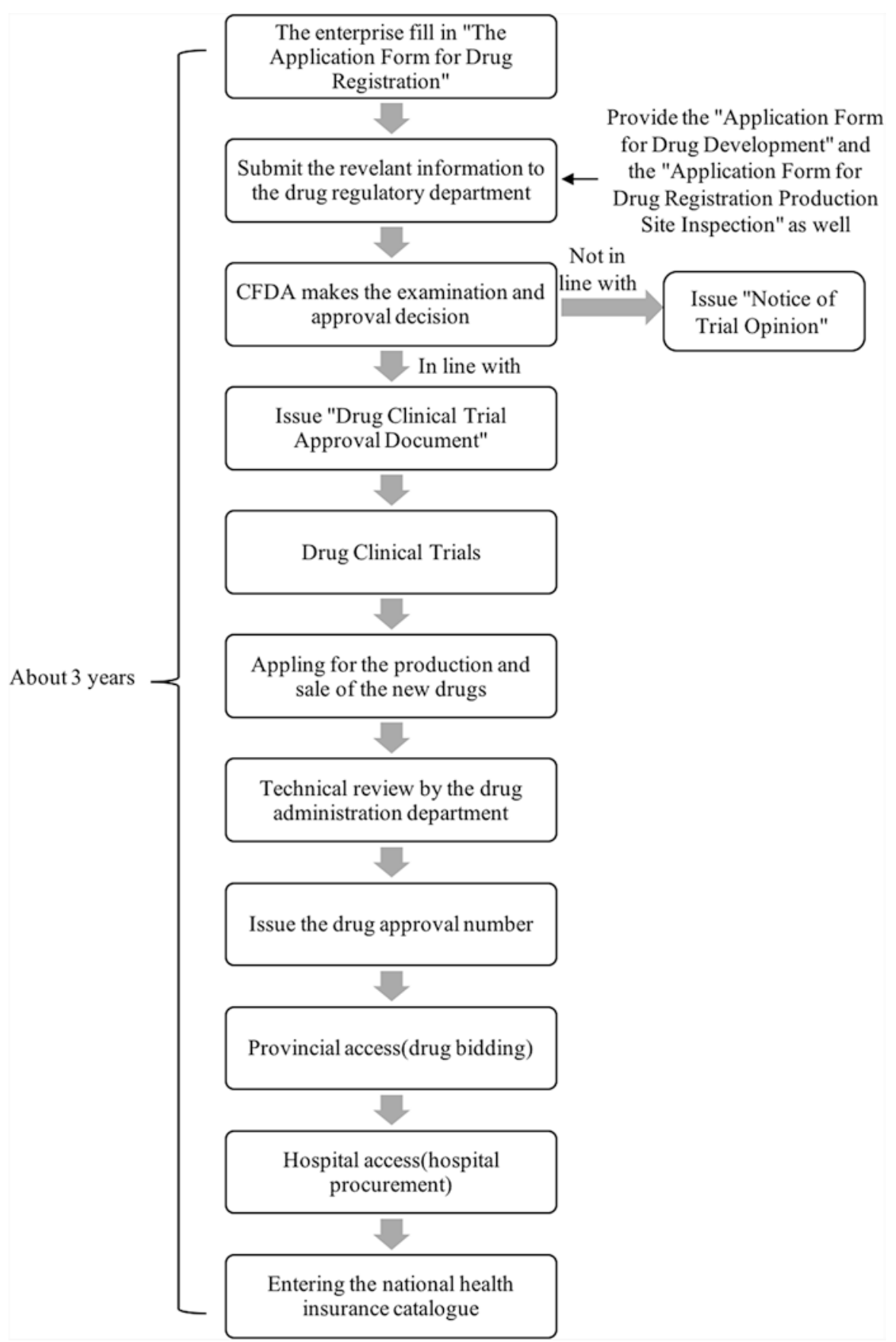

Fig. 7 Flow chart of generic drug registration and approval process in China 
Table 2 Summary of China's drug price management policies

\begin{tabular}{|c|c|c|}
\hline Year & Policies and regulations & Relevant content \\
\hline 1954 & $\begin{array}{l}\text { Additional drug price } \\
\text { policy for hospitals (Yuan } \\
\text { 2005) }\end{array}$ & $\begin{array}{l}\text { An addition of price on the basis of the purchase price } \\
\text { when selling drugs to allow the hospital to form a retail } \\
\text { price for drugs. Additional rate of drugs: Western } \\
\text { medicine shall not exceed } 15 \% \text {, traditional Chinese } \\
\text { medicines shall not exceed } 16 \% \text {, Chinese herbal } \\
\text { medicines shall not exceed 29\% (Sun 2001) }\end{array}$ \\
\hline 2000 & $\begin{array}{l}\text { Government drug pricing } \\
\text { method (Wang 2012) }\end{array}$ & - \\
\hline 2000 & $\begin{array}{l}\text { Notice on issues related to } \\
\text { the development of } \\
\text { separate pricing drugs }\end{array}$ & $\begin{array}{l}\text { If the same type of drugs on the domestic market are } \\
\text { produced by a number of enterprises, as long as one of } \\
\text { those companies provides evidence that their product } \\
\text { quality, effectiveness, safety treatment cycle or treatment } \\
\text { costs were significantly better/lower than that of other } \\
\text { companies, and therefore not suitable to follow pricing } \\
\text { policy, this company can apply for a separate pricing. In } \\
\text { addition, the original drug owner that has IP rights whose } \\
\text { protection period expired may also apply for separate } \\
\text { pricing }\end{array}$ \\
\hline 2001 & $\begin{array}{l}\text { Notice on issues related to } \\
\text { the development of } \\
\text { separate pricing drugs }\end{array}$ & $\begin{array}{l}\text { Separate pricing application needs to be submitted to } \\
\text { local or provincial price administration department, } \\
\text { which would be further transferred to National } \\
\text { Development and Reform Commission }\end{array}$ \\
\hline 2005 & $\begin{array}{l}\text { National Development and } \\
\text { Reform Commission: } \\
\text { directory for fixed price } \\
\text { drugs }\end{array}$ & - \\
\hline 2009 & $\begin{array}{l}\text { Opinions on deepening the } \\
\text { reform of medical and } \\
\text { health system }\end{array}$ & $\begin{array}{l}\text { Reforming the mechanism of drug price formation and } \\
\text { using price leverage to encourage enterprises to innovate } \\
\text { independently (Wang 2012) }\end{array}$ \\
\hline 2009 & $\begin{array}{l}\text { Opinions on reforming the } \\
\text { mechanism of price } \\
\text { formation for } \\
\text { pharmaceuticals and } \\
\text { medical services (State } \\
\text { Council) }\end{array}$ & $\begin{array}{l}\text { Original drugs whose IP protection period has expired } \\
\text { were renamed model for generic drugs. Measures were } \\
\text { proposed to gradually narrow the price gap with generic } \\
\text { drugs (Wang 2012) }\end{array}$ \\
\hline 2009 & Price law & - \\
\hline 2009 & $\begin{array}{l}\text { Rules of price parities } \\
\text { between drugs }\end{array}$ & 然 \\
\hline 2010 & $\begin{array}{l}\text { Management measures of } \\
\text { drug prices (Draft) }\end{array}$ & $\begin{array}{l}\text { For the original drug whose IP protection period has } \\
\text { expired, the government department in charge of price } \\
\text { can have price adjustment every } 2-3 \text { years, during which } \\
\text { the government-guided price reduction is generally no } \\
\text { less than } 15 \% \text { (Wang 2012) }\end{array}$ \\
\hline 2010 & $\begin{array}{l}\text { Notice on reducing the } \\
\text { highest retail prices of } \\
\text { some drugs such as } \\
\text { ceftriaxone }\end{array}$ & $\begin{array}{l}\text { Reducing the maximum retail price of some separate } \\
\text { pricing drugs, and disqualifying separate pricing of some } \\
\text { separate-priced medicines (Wang 2012) }\end{array}$ \\
\hline
\end{tabular}


Table 2 (continued)

\begin{tabular}{|c|c|c|}
\hline Year & Policies and regulations & Relevant content \\
\hline \multirow[t]{2}{*}{2011} & $\begin{array}{l}\text { Notice on adjusting the } \\
\text { highest retail price of } \\
\text { certain antimicrobial and } \\
\text { circulatory system drugs }\end{array}$ & \multirow[t]{2}{*}{-} \\
\hline & $\begin{array}{l}\text { Notice on adjusting the } \\
\text { price of hormones, } \\
\text { regulating endocrine and } \\
\text { nervous system drugs and } \\
\text { relevant issues }\end{array}$ & \\
\hline 2015 & $\begin{array}{l}\text { Start of the first pilot } \\
\text { project on drug price } \\
\text { negotiations }\end{array}$ & $\begin{array}{l}\text { Five varieties, including patented drugs for the treatment } \\
\text { of hepatitis B, lung cancer and multiple myeloma, were } \\
\text { selected as pilot drugs for price negotiation, of which } \\
\text { three varieties have went through successful negotiations }\end{array}$ \\
\hline 2015 & $\begin{array}{l}\text { Notice on Issuing Some } \\
\text { Opinions on Controlling } \\
\text { Unreasonable Growth of } \\
\text { Medical Expenses in } \\
\text { Public Hospitals }\end{array}$ & - \\
\hline \multirow[t]{2}{*}{2016} & $\begin{array}{l}\text { Announcement of the } \\
\text { result of the first } \\
\text { negotiations over drug } \\
\text { prices }\end{array}$ & $\begin{array}{l}\text { Tenofovir disoproxil (brand name, Viread), icotinib } \\
\text { (brand name, Conmana) and gefitinib (brand name, } \\
\text { Iressa) were the three varieties successfully negotiated, } \\
\text { whose prices fell by more than } 50 \%\end{array}$ \\
\hline & $\begin{array}{l}\text { Catalogue of national } \\
\text { basic medical insurance, } \\
\text { industrial injury insurance } \\
\text { and maternity insurance } \\
\text { drugs (2017 edition) }\end{array}$ & $\begin{array}{l}\text { Identified } 44 \text { products to enter the negotiation for the new } \\
\text { national directory of Medicare and added a new list of } 45 \\
\text { to-be-negotiated drugs }\end{array}$ \\
\hline
\end{tabular}

Table 3 Three-stage development of price controls on drug (Liu 2012)

\begin{tabular}{l|l|l}
\hline Stage & Period & Content \\
\hline Stage-I & $\begin{array}{l}1978- \\
\text { late } \\
1980 \mathrm{~s}\end{array}$ & $\begin{array}{l}\text { 1. The comprehensive control of drug prices was changed into partial } \\
\text { liberalization. The government adjusted the ex-factory price, the selling } \\
\text { price and the distribution rate of the drug whose prices deviated from its } \\
\text { true value too much }\end{array}$ \\
\cline { 3 - 3 } $\begin{array}{l}\text { 2. Unrealistically high prices of drugs appeared: the state-controlled } \\
\text { drug production price is based on the reported production costs plus } \\
5 \% \text { profit margin, the wholesale price is the production price plus 15\%, } \\
\text { the retail price is the wholesale price plus 15\%. Due to the fixed } \\
\text { additional rate, wholesalers and retailers prefer expensive drugs. } \\
\text { Registration of new drugs has also been used as a means of obtaining } \\
\text { high prices }\end{array}$ \\
\hline Stage-II & $\begin{array}{l}\text { Late } \\
1980 s- \\
\text { mid } \\
1990 s\end{array}$ & $\begin{array}{l}\text { By 1994 most drug prices were handed over to market mechanism from } \\
\text { the government. As a result of soaring pharmaceutical prices, poor } \\
\text { quality control, corruption and kickbacks, pricing control was } \\
\text { reintroduced by the government in 1997 }\end{array}$ \\
\hline Stage- & $\begin{array}{l}\text { Since } \\
\text { Iate } \\
\text { III }\end{array}$ & $\begin{array}{l}\text { Re-regulating part of the drug prices and continuing to launch a wide } \\
\text { range of mandatory price-cutting operations. Since 1997, the } \\
\text { government has been continuously reducing drug prices of different } \\
\text { ranges. At present about 60\% of the drug prices are under the } \\
\text { government's control }\end{array}$ \\
\hline
\end{tabular}




\section{B. Government pricing}

The drugs included in the government's pricing range shall be priced by the government except for a few special varieties, and enterprises may not adjust prices on their own. The government uses the traditional cost-plus pricing method to set the maximum retail price and stipulates the sales profit margin and the circulation rate. Pharmaceutical companies can apply for separate pricing of government-priced drugs.

\section{Enterprise autonomous pricing}

As for the enterprise autonomous pricing drugs, the price should be submitted to corresponding price control administration department ${ }^{4}$ to undergo examination and then publish relevant price online.

\subsection{Regulatory Policies on Industrial Structure and Layout}

The relevant policies and regulations on pharmaceutical industry mainly focus on plant environment, business sites, equipment and facilities, storage conditions, personnel qualifications, management organization system, industrial structure and layout policies (see Table 4). Those policies and regulations made clear the structural adjustment and developmental direction of the pharmaceutical industry, rationalized the industrial structure of pharmaceutical enterprises and regulated the regional spatial planning and layout adjustment of pharmaceutical enterprises.

\section{The Market Structure of China's Pharmaceutical Industries}

\subsection{The High Expenditure Rate Under China's Medicare System}

By the end of 2010, under China's Medicare system (National Basic Medical Insurance System), people participating in urban basic medical insurance totalled 432.06 million and participants in the new rural cooperative medical care reaching 835.6 million, with a participation rate of $96 \%$.

However, as shown in Fig. 8, the annual expenditure of basic medical insurance funds for urban workers exceeded $70 \%$ of the total income. The fund expenditure of the new rural cooperative medical care showed a more alarming annual increase trend, reaching as high as $97.72 \%$ of fund revenue in 2009 . The high expenditure rate is a serious threat to the ability of Medicare funds to withstand risks (Wang 2012).

\footnotetext{
${ }^{4}$ Prior to 2015, price control administration in China was generally conducted by National Price Administration Bureau and later changed to Price Control Administration Department under National Development and Reform Commission.
} 
Table 4 Summary of China's pharmaceutical industry structure and layout policies

\begin{tabular}{|c|c|c|}
\hline Year & Policies and regulations & Relevant content \\
\hline 2007 & $\begin{array}{l}\text { Biological industry } \\
\text { development under the } \\
\text { "Eleventh Five-Year } \\
\text { Plan" }\end{array}$ & $\begin{array}{l}\text { Planning to speed up the development of biopharmaceutical } \\
\text { industry (Li and Yang 2016) }\end{array}$ \\
\hline 2009 & $\begin{array}{l}\text { A number of policies to } \\
\text { promote the } \\
\text { development of } \\
\text { biological industry }\end{array}$ & $\begin{array}{l}\text { The biopharmaceutical industry will be nurtured as a pillar } \\
\text { industry in the high-tech field ( } \mathrm{Li} \text { and Yang 2016) }\end{array}$ \\
\hline 2010 & $\begin{array}{l}\text { Guiding opinions on } \\
\text { accelerating the } \\
\text { structural adjustment of } \\
\text { the pharmaceutical } \\
\text { industry }\end{array}$ & e \\
\hline 2011 & $\begin{array}{l}\text { Pharmaceutical industry } \\
\text { under the "Twelfth } \\
\text { Five-Year" plan }\end{array}$ & $\begin{array}{l}\text { Relevant departments appropriated about RMB } 40 \text { billion } \\
\text { for research, development and creation of major new drugs } \\
\text { in the biomedical industry. The central government } \\
\text { allocated RMB10 billion, and the remaining funds were } \\
\text { provided by local governments and enterprises. The total } \\
\text { amount is more than double of the amount of the "Eleventh } \\
\text { Five-Year" (Li and Yang 2016) }\end{array}$ \\
\hline 2012 & $\begin{array}{l}\text { Bioindustry } \\
\text { development plan }\end{array}$ & - \\
\hline 2016 & $\begin{array}{l}\text { Pharmaceutical industry } \\
\text { "Thirteenth Five-Year" } \\
\text { plan }\end{array}$ & $\begin{array}{l}\text { The state will start to set up a policy environment that } \\
\text { adapts to the original medicine research from the } \\
\text { perspectives of finance, examination, approval, bidding, } \\
\text { insurance and patents }\end{array}$ \\
\hline 2016 & $\begin{array}{l}\text { Pharmaceutical industry } \\
\text { development planning } \\
\text { guide }\end{array}$ & $\begin{array}{l}\text { Attach importance to the international registration of new } \\
\text { drugs, generic drugs, traditional Chinese medicines and } \\
\text { bio-analogues. Take priority over making } 3-5 \text { new drugs } \\
\text { and over } 200 \text { chemical generic drugs in the market in } \\
\text { developed countries (Meng 2017) }\end{array}$ \\
\hline
\end{tabular}

\subsection{The Dominant Mode of Monopoly by Hospitals}

Hospitals in China almost monopolized the drug sales market, whose market share was once as high as 95\% (Wu 2006), and nowadays they still control about 4/5 of the market (Sun et al. 2008). The reasons for such a monopoly are as follows:

\subsubsection{The "Hospital and Pharmacy Together" Model Facilitates Drug Sales by Hospitals}

The hospital has its own pharmacy; most patients are accustomed to receiving medical treatment in hospitals and purchasing medicines in hospital pharmacies (Liu 2012). 


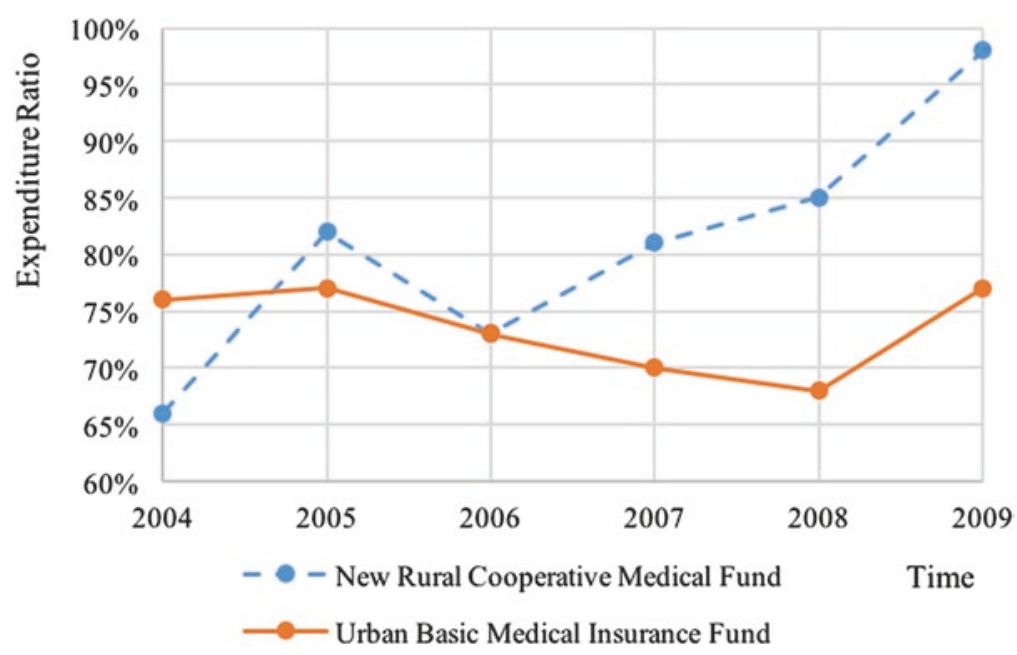

Fig. 8 Expenditure of Medicare fund in China (2004-2009)

National Health Commission of the PRC, 2011 China Health Statistics Summary, http://www. nhfpc.gov.cn/cmsresources/mohbgt/cmsrsdocument/doc12294.pdf. National Bureau of Statistics, China Statistical Yearbook 2007 http://www.stats.gov.cn/tjsj/ndsj/2007/indexch.htm

\subsubsection{The "Hospitals Supported by Medicines" Phenomenon Provides Hospitals with Monopoly Power}

From 2003 to 2010, China's medical institutions have a price increase of $15 \%$ on drugs, and the proportion of drug revenues in the revenue composition of public hospitals ${ }^{5}$ is only slightly behind that of medical revenues, with a stable rate of over $40 \%$ (see Fig. 9). According to China Statistical Yearbook 2010, the total revenue of government-run medical institutions in China reached RMB 74,569,116 million in 2009, of which drugs revenue was RMB 31,360,277 million RMB, accounting for $42.1 \%$ of the total (Liu 2012).

\subsubsection{Drug Management Policies Conducive to Monopoly}

Prescription drugs are generally controlled by doctors when patients go to the hospital for treatment. Hospitals usually take various measures to control the outflow of prescriptions drugs. In most cases, patients can only buy prescription drugs from hospital pharmacies, resulting in hospitals becoming the dominant drug distributors. In addition, the site-specific restrictions by Medicare also make patients buy medicines at hospital pharmacies in most cases (Liu 2012) (Table 5).

\footnotetext{
${ }^{5}$ In China, public hospitals (or government-run hospitals, which are established and supported by regular government budget) and private hospitals are the two major resource of medical service. Although they are similar in number (13,069 public vs. 14,509 private ones in 2015), the public hospitals are far more important than private ones in terms of practical service (public hospitals provided service up to 2.71 billion person/times in 2015, private ones only 0.37 billion person/ times, which primarily could be attributed to higher quality and professionalism of the public hospitals. Available via http://www.360doc.com/content/17/0610/13/38907157_661600475.shtml
} 


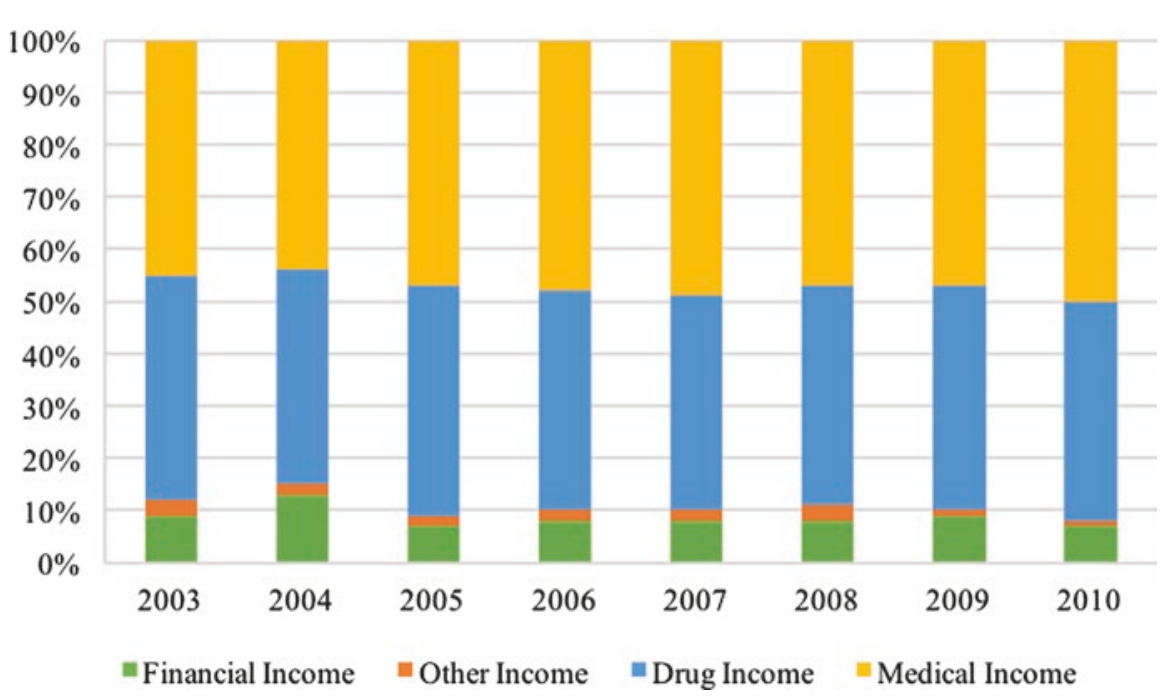

Fig. 9 Revenue in government-run hospitals in China (2003-2010)

The website of Ministry of Health Statistical Information, 2004-2010 Health Statistics Yearbook, 2011 Health Statistics

Table 5 China's drug administration policies leading to hospital monopoly (Liu 2012)

\begin{tabular}{|c|c|c|}
\hline Year & Policies and regulations & Relevant content \\
\hline 1999 & $\begin{array}{l}\text { Pilot work of prescription } \\
\text { drugs and non-prescription } \\
\text { drug circulation }\end{array}$ & Officially launched \\
\hline 1999 & $\begin{array}{l}\text { Provisional regulations on } \\
\text { the circulation management } \\
\text { of prescription drugs and } \\
\text { non-prescription drugs }\end{array}$ & $\begin{array}{l}\text { Requiring drug administration at all levels to effectively } \\
\text { promote drug classification management }\end{array}$ \\
\hline 2001 & Drug administration law & $\begin{array}{l}\text { The government implements the system of the } \\
\text { classification and management of prescription drugs } \\
\text { and non-prescription drugs, the specifics of which are } \\
\text { formulated by the State Council }\end{array}$ \\
\hline 2004 & - & $\begin{array}{l}\text { About } 400 \text { kinds of antibiotics, amines, } \\
\text { antituberculosis, antifungal and norethindrone shall be } \\
\text { prescribed by a licensed practitioner }\end{array}$ \\
\hline 2006 & $\begin{array}{l}\text { The second national drug } \\
\text { classification management } \\
\text { conference }\end{array}$ & $\begin{array}{l}\text { Drug retail outlets across the country shall not sell nine } \\
\text { types of drugs, such as narcotic drugs. Drug retailers } \\
\text { must place prescription drugs and non-prescription } \\
\text { drug over different counters. And no advertisements or } \\
\text { advertisements in disguise may be published in the } \\
\text { mass media for prescription drugs }\end{array}$ \\
\hline
\end{tabular}


Table 6 Top 10 medicines in terms of sales value in 2015

\begin{tabular}{l|l|c}
\hline Drug name & $\begin{array}{l}\text { Sales value (RMB } \\
\text { billion) }\end{array}$ & $\begin{array}{l}\text { Year-on-year growth } \\
\text { rate }(\%)\end{array}$ \\
\hline Sodium chloride injection & 15.85 & 9.77 \\
\hline Glucose injection & 10.37 & 16.90 \\
\hline Clopidogrel hydrogen sulphate tablets & 9.24 & 3.62 \\
\hline Pantoprazole sodium for injection & 9.23 & 7.50 \\
\hline Omeprazole sodium for injection & 8.94 & 16.51 \\
\hline Ceftizoxime sodium for injection & 8.33 & 11.28 \\
\hline Human albumin & 8.21 & 8.65 \\
\hline Injection thrombus & 8.04 & -4.32 \\
\hline $\begin{array}{l}\text { Monosialotetrahexosylganglioside sodium } \\
\text { injection }\end{array}$ & 7.80 & 4.73 \\
\hline Cefoxitin sodium for injection & 7.50 & 5.60 \\
\hline Total & 93.51 & \\
\hline
\end{tabular}

Source: Zhong Kang CMH: http://drug.39.net/a/160318/4792071.html

\subsubsection{The Supply and Demand Characteristics of the Medical Industry Conducive to Monopoly}

Patients lack relevant information on the choice of drugs, and their price elasticity of demand for medicines is low. The hospital is both a provider of medical products and a determinant of the demand for medical products; the doctor has the ability to conduct supplier-induced needs. There is serious information asymmetry between doctors and patients in the medical industry. Patients have obvious information disadvantages in the selection of treatment plans and drug efficacy. The hospital has the initiative on the treatment plans and drug selection (Liu 2012).

\subsection{China's Generic Drug Market}

\subsubsection{Generic Drugs Occupy the Drug Markets}

According to statistics, global sales of the patent-expired drugs amount to US $\$ 77$ billion during 2011-2015 (Liu 2010). According to China Health-Care Industry 2016 (Blue Book), the total revenue of China's pharmaceutical market (covering chemical medicine, Chinese traditional medicine and biopharmaceuticals) reached RMB 1335.4 billion, of which chemical drugs were RMB 888.0 billion, accounting for $66.5 \%$, while revenue of Chinese traditional medicines accounted for $25.3 \%$ and biopharmaceutical $8.2 \%$. Among all the chemicals, generic drugs have a market share of $95 \%$, while the market share of patented drugs and original drugs is only about $5 \%$ in total. The market of patented drugs is only RMB 12 billion, less than $1 \%$ of the domestic pharmaceutical market.

Following typical medicines are on the top lists of market sale, also typical in generic drugs (see Table 6). 


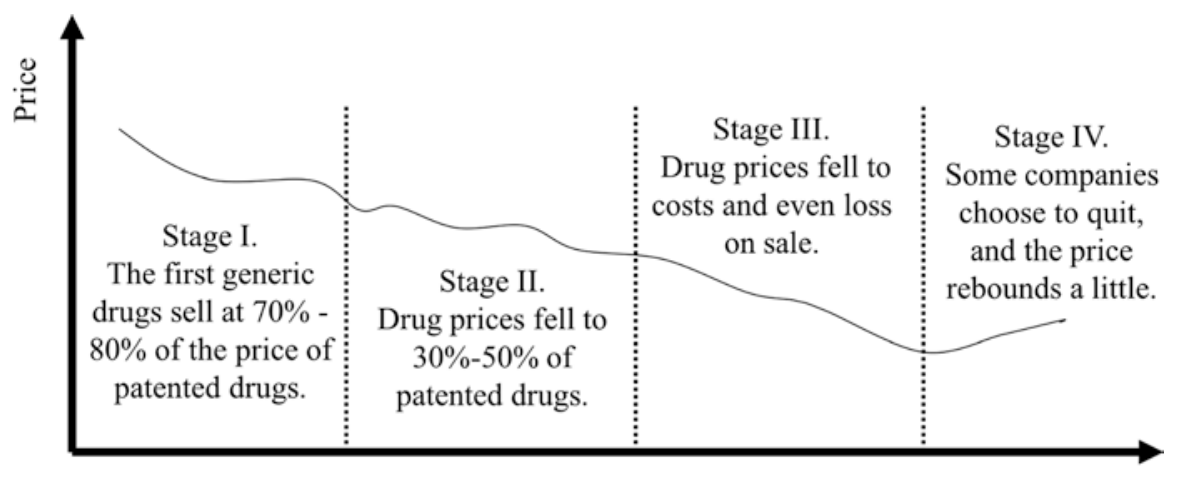

Time

Fig. 10 Generic drugs' price movements after the expiration of the patent (Wang 2013)

\subsubsection{The Opportunities upon Patent Expiration}

The expiration of the protection term of a patented drug gives generic manufacturers huge opportunities for profit-making. However, with the passage of time, this opportunity will gradually diminish and eventually vanish (Fig. 10). This is due to "price competition only" when the market is filled with too many competitors whose products in the market are almost the same. Figure 10 illustrates this scenario in I to IV stages. ${ }^{6}$

There are interesting movements in pharmaceutical-related stock markets during the patent expiration period. For example, some 16 companies have possessed the opportunity to avail themselves of the benefits of timely expiration of patents in the specialty pharmaceutical business and experienced a dramatic price hike (see Table 7).

The most successful case was Hisun Pharmaceutical, whereby the company obtained a huge profit in 2003 and 2004 when the patents of simvastatin and pravastatin (which were the main products of the company) expired (see Table 8).

\footnotetext{
${ }^{6}$ These four stages can be further explained: I Right Entrance period, to produce drugs just after the expiration of the patent, with producer enjoying $70 \%$ to $80 \%$ of original price on the previous patented drugs; II Crowded Market period, long after the expiration of the patent, with producer enjoying $30 \%$ to $50 \%$ of the patented drugs; III Crowding Out period, when the drug price drops to almost production cost or even lower, with some producers having to quite or leave the market; and IV Recovery period, after some companies leave the market, fewer producers and productions may raise the drug price again.
} 
Table 7 Stock price change of 16 sample companies around patent expiration date (Wang 2013)

\begin{tabular}{|c|c|c|c|c|c|c|}
\hline Company name & $\begin{array}{l}\text { Six } \\
\text { months } \\
\text { before } \\
\text { patent } \\
\text { expiry }\end{array}$ & $\begin{array}{l}\text { Three } \\
\text { months } \\
\text { before } \\
\text { patent } \\
\text { expiry }\end{array}$ & $\begin{array}{l}\text { Patent } \\
\text { expiry } \\
\text { date }\end{array}$ & $\begin{array}{l}\text { Three } \\
\text { months } \\
\text { after } \\
\text { patent } \\
\text { expiry }\end{array}$ & $\begin{array}{l}\text { Six } \\
\text { months } \\
\text { after } \\
\text { patent } \\
\text { expiry }\end{array}$ & $\begin{array}{l}\text { Expiry date of } \\
\text { patented drugs }\end{array}$ \\
\hline $\begin{array}{l}\text { Hisoar } \\
\text { Pharmaceutical }\end{array}$ & 3.86 & 6.34 & 7.67 & 7.72 & 13.72 & 2010/4/13 \\
\hline $\begin{array}{l}\text { Huahai } \\
\text { Pharmaceutical }\end{array}$ & 4.31 & 5.07 & 5.60 & 6.79 & 11.08 & $2006 / 12 / 22$ \\
\hline $\begin{array}{l}\text { Huahai } \\
\text { Pharmaceutical }\end{array}$ & 7.62 & 7.14 & 12.79 & 14.55 & 15.92 & $2009 / 11 / 15$ \\
\hline $\begin{array}{l}\text { Hisun } \\
\text { Pharmaceutical }\end{array}$ & 4.49 & 9.57 & 9.76 & 7.64 & 14.03 & $2007 / 8 / 28$ \\
\hline $\begin{array}{l}\text { Hisun } \\
\text { Pharmaceutical }\end{array}$ & 11.91 & 15.09 & 15.79 & 14.90 & 24.43 & 2010/4/12 \\
\hline Hengrui Medicine & 3.17 & 4.33 & 4.89 & 6.45 & 9.79 & $2006 / 9 / 8$ \\
\hline Hengrui Medicine & 14.76 & 16.21 & 16.42 & 18.24 & 22.25 & $2009 / 3 / 22$ \\
\hline Hengrui Medicine & 25.93 & 24.63 & 27.54 & 25.34 & 36.71 & $2010 / 5 / 25$ \\
\hline $\begin{array}{l}\text { Jincheng } \\
\text { Pharmaceutical }\end{array}$ & 12.00 & 11.48 & 13.80 & 16.01 & - & 2012/7/18 \\
\hline $\begin{array}{l}\text { Topfond } \\
\text { Pharmaceutical }\end{array}$ & 5.27 & 5.80 & 5.86 & 7.94 & 11.26 & $2009 / 10 / 27$ \\
\hline Livzon Group & 22.30 & 27.60 & 31.63 & 37.58 & 47.81 & $2009 / 10 / 26$ \\
\hline $\begin{array}{l}\text { Baiyunshan } \\
\text { Pharmaceutical A }\end{array}$ & 9.23 & 11.60 & 14.32 & 12.26 & 18.40 & $2010 / 4 / 30$ \\
\hline NHWA & 13.61 & 16.71 & 19.72 & 22.72 & 23.63 & $2010 / 5 / 17$ \\
\hline Salubris & 18.43 & 23.36 & 25.47 & 39.50 & 37.61 & $2010 / 2 / 12$ \\
\hline Joincare & 4.10 & 5.32 & 5.99 & 8.13 & 8.60 & $2009 / 10 / 8$ \\
\hline $\begin{array}{l}\text { Beilu } \\
\text { Pharmaceutical }\end{array}$ & 10.53 & 8.81 & 9.34 & 14.10 & 12.71 & $2012 / 5 / 15$ \\
\hline
\end{tabular}

Data sources: WIND, FDA and companies' announcement

Note: the stock price boom cases here are generally for special API drugs and imitating drugs

\section{$5 \quad$ IP Structure in Pharmaceutical Industries in China}

\subsection{The Patented Drug Market}

\subsubsection{The Demand for Drugs Against Infectious Diseases Relies on Patented Drugs}

The key public health issues in China are infectious diseases and chronic diseases ( $\mathrm{Li}$ and Lv 2002). According to statistics from National Bureau of Disease Prevention and Control of the National Health Planning Commission, the incidence of notifiable infectious diseases reported by China in 2015 was $470.35 / 100,000$, and the reported death rate was 1.23/100,000. Now in China the treatment of most infectious diseases such as chronic hepatitis B, AIDS and other diseases depends on imported patented drugs, which are expensive due to their clinical efficacy (Jiang et al. 2017). 
Table 8 Events which Hisun that seized the opportunities upon patent expiry (Wang 2013)

\begin{tabular}{|c|c|c|c|}
\hline Year/month & Event & $\begin{array}{l}\text { Responses of Hisun } \\
\text { Pharmaceutical }\end{array}$ & Effective \\
\hline $2003 / 05$ & $\begin{array}{l}\text { The patent of Merck's } \\
\text { second largest drug } \\
\text { Simvastatin registered } \\
\text { in the European Union } \\
\text { (EU) expired }\end{array}$ & $\begin{array}{l}\text { They finished the R\&D of } \\
\text { the production process } \\
\text { ahead of schedule and } \\
\text { started mass production. } \\
\text { They received a large } \\
\text { number of orders after } \\
\text { multiple negotiations with } \\
\text { Merck, and their sales } \\
\text { increased rapidly }\end{array}$ & $\begin{array}{l}\text { The growth rate of the } \\
\text { main business income is } \\
103.45 \% \text { in } 2003 \text {, which } \\
\text { ranked the fifth in "Top } \\
10 \text { enterprises in the } \\
\text { chemical raw material } \\
\text { manufacturing industry" }\end{array}$ \\
\hline $2004 / 08$ & $\begin{array}{l}\text { The patent of the } \\
\text { pravastatin (owned } \\
\text { originally by Daiichi } \\
\text { Sankyo, a Japanese } \\
\text { pharmaceutical } \\
\text { company) in the EU } \\
\text { market expired }\end{array}$ & $\begin{array}{l}\text { Hisun's pravastatin patents } \\
\text { passed Certificate of } \\
\text { Suitability (COS) } \\
\text { certification earlier than } \\
\text { patent expiration. After } \\
\text { the product patent expired, } \\
\text { Hisun conducted a wide } \\
\text { range of sales before the } \\
\text { process patent expires }\end{array}$ & $\begin{array}{l}\text { The company's stock } \\
\text { price rose from } 4 \text { RMB in } \\
\text { February } 2004 \text { to over } 5 \\
\text { RMB at the end of } 2004 \text {, } \\
\text { while the pharmaceutical } \\
\text { bio-index dropped nearly } \\
30 \% \text { over the same period }\end{array}$ \\
\hline
\end{tabular}

Note: The process patent expiry is generally later than the product patent expiry

According to the data from Publicity Department of the National Health Planning Commission, in 2012, the national statistics on the death rate of chronic diseases was $533 / 100,000$, accounting for $86.6 \%$ of the total number of deaths. Almost all of the clinical standard medicines used in these areas of chronic diseases are patented drugs or patent-expired drugs (Jiang et al. 2017).

\subsubsection{Patented Drugs Are More Profitable Than Generic Drugs}

Patentees of patented drugs enjoy the market exclusivity to the products for a long time. The ultra-high profits during the market exclusivity period are the targets pursued by the pharmaceutical companies (Chen and Liu 2006).

In 2010, there were 303 varieties of patent-expired drugs in China, which were produced or distributed by 315 pharmaceutical companies, including 253 foreignowned enterprises (81\%), 61 joint ventures (19\%) and only 1 domestic enterprise. Compared with the generic drugs companies, the 116 foreign and joint ventures that produced the corresponding patent-expired drugs accounted for $56.4 \%$ of the market sales and $52.1 \%$ of the total sales (PAC 2010).

\subsubsection{National Drug Price Negotiations Increased the Sales of Patented Drugs}

National drug price negotiations have brought huge market gains to patented drugs. The drop in the price of patented drugs has enabled more patients to pay for medicines, and the clinical demand for patent drugs has increased. So the sales of patent drugs have risen (Jiang et al. 2017). 


\subsubsection{The Patent Linkage System Is Imperfect}

Patent linkage means that when a drug manufacturer applies for registration of generic drugs with China Food and Drug Administration (CFDA), CFDA will have to consider the status of the patent involved to balance the interests of all parties (Xiao 2017).

\section{A. Strict restrictions on the registration of generic drugs}

Article 19 of Provisions for Drug Registration provides that "Applicants other than the patentee may submit the application for registration two years prior to the expiry date of the patent", "After the expiry date of the patent, check and issue the drug approval number, Import Drug License or Pharmaceutical Product License if the application conforms with the provisions", respectively, made rules on generic drug registration application time and the effective date of the provisions. However, can the regulations promote the generic drugs listed timely and increase the availability of public medicines? There are many questions in academia about this (Fang 2013).

\section{B. Imperfect patent information registration requirements}

Some imperfections exist in Article 18 of the Provisions for Drug Registration, such as "The applicant shall provide the applicant's or others' patents in China with their prescriptions, techniques, uses, etc. for the drug to which they are applying for registration, and provide the state of patent ownership", where the word "etc." is ambiguous and has not been elaborated upon (Fang 2013).

\section{Single dispute resolution approach}

Article 18 of the Provisions for Drug Registration stipulates that "Disputes over patent rights in the course of drug registration shall be resolved in accordance with the laws and regulations of the relevant patent". CFDA will issue a notice stating that the application infringes the patent rights of others and require it to resolve the patent dispute on its own; otherwise no further examination will be conducted. However, according to Chinese Patent Law, this behaviour in the process of drug registration does not belong to the realm of patent infringement. The patentee has no basis for prosecution; generic drug companies cannot respond to the defence. For generic drug companies, the current defence approach is too monotonous, and it can only declare to the State IP Office that the patent in question is invalid (Fang 2013).

\subsubsection{Domestic Patented Drugs Far Fewer Than Imported Patented Drugs}

Nearly $90 \%$ of the patented drugs come from foreign enterprises (Jiang et al. 2017). So far, there are only two innovative drugs originated from China that have been internationally recognized, namely, artemisinin and Sodium Dimercaptosuccinate. Meanwhile, large overseas multinational pharmaceutical companies generally bring 2-3 new patents with new chemical entities to market each year (Liu 2012). 
There are mainly two categories of patented drugs in China. One is the 265 exclusively patented drugs approved for import, of which 48 have got core patents in China, accounting for $18.1 \%$ of imported patented drugs. The other is the 22 first type of new drugs ${ }^{7}$ in China, of which only 6 have core patents in China. The ratio between imported patented drugs and domestic patented drugs (those with core patents) is about 8:1 (Jiang et al. 2017).

\subsection{The Characteristics of Typical Self-Developed Patented Drugs}

\subsubsection{Polymorphic Drug Patents}

Drug polymorphism refers to the presence of drugs in two or more different crystalline states. It refers to a solid pharmaceutical polymorphic ingredient present in a particular crystalline form state, particularly solid chemicals (Zhang et al. 2016).

As shown in Fig. 11, annual patent application for polymorphic drugs has increased significantly in China in the last three decades. Between 1985 and 1994, the total number of patent applications for polymorphic drugs was only $30(0.8 \%$ of the total). However, from 1995 to 2004, the total number of patent applications was 471 , accounting for $12.6 \%$ of the total, with an average annual number of 47 applications and an average annual growth rate of 114.9\%. From 2005 to 2014, the total number of patent applications was as high as $3009,78.9 \%$ of the total, an average of 301 applications each year, with the average annual growth rate of up to $147.9 \%$ (Fig. 12).

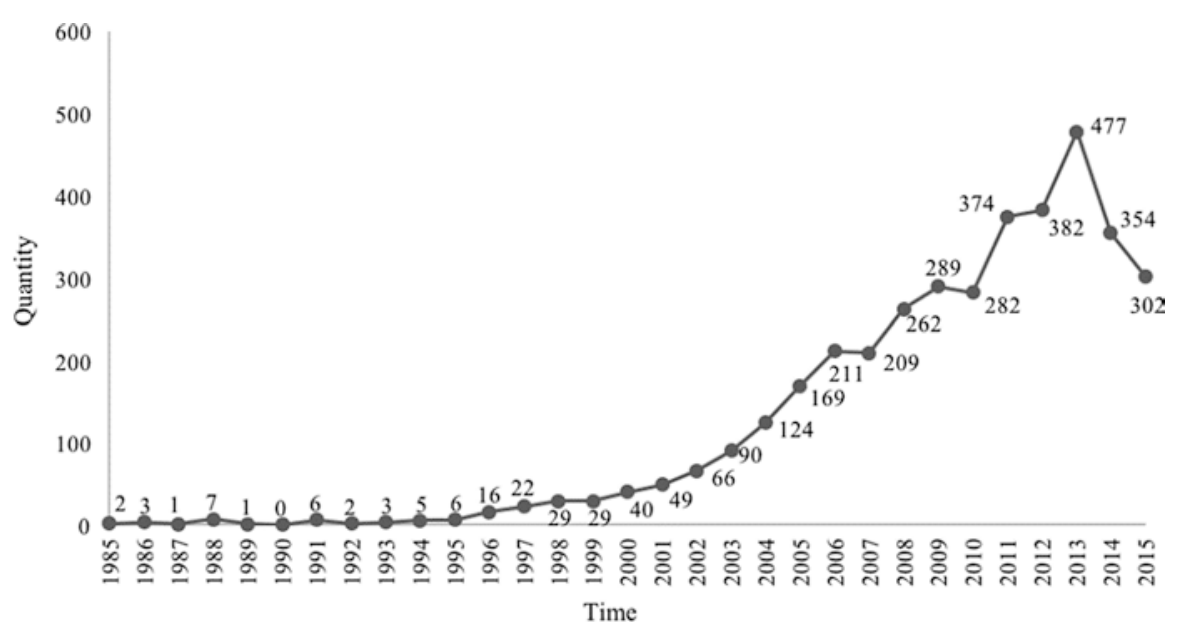

Fig. 11 Annual patent application volume related to polymorphic drugs (1985-2015) (Wang et al. 2017)

${ }^{7}$ The first type of new drugs refers to chemical drugs and biological products. 


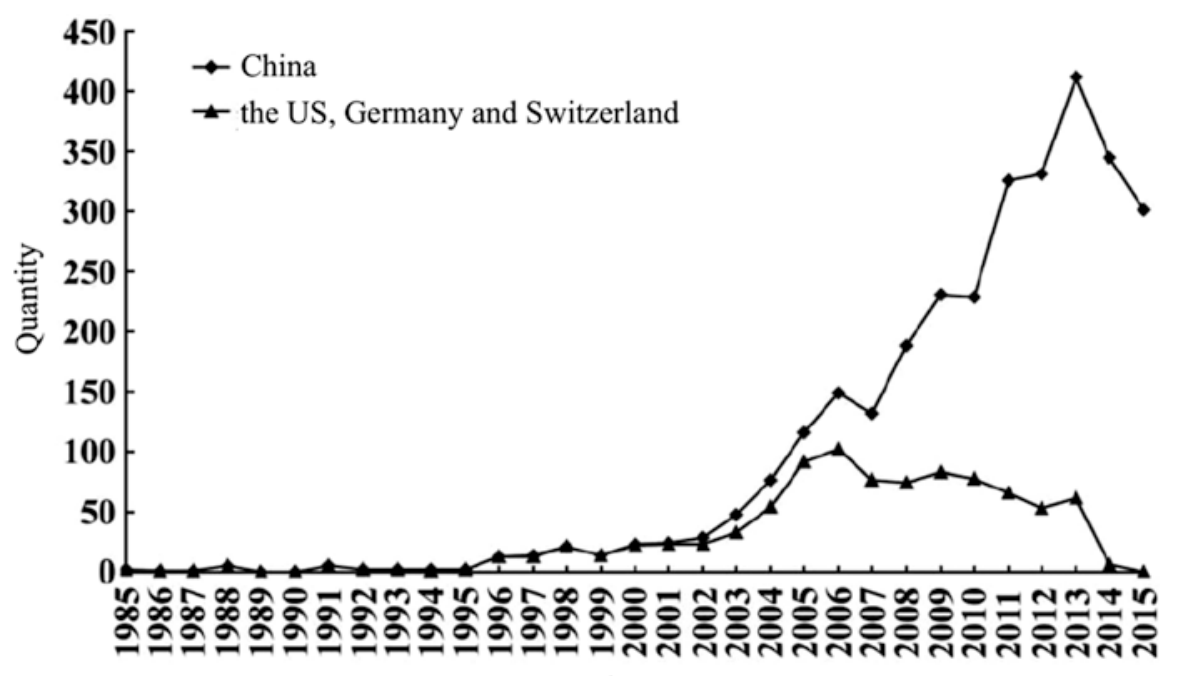

Time

Fig. 12 Trends of polymorphic drug patent applications in China by applicants from China and the United States, Germany and Switzerland (1985-2015) (Wang et al. 2017)

As shown in Fig. 13, the majority of polymorphic drug patent applicants in China are enterprises, which are marked as deep black.

Figure 14 shows the polymorphic drug patent applicants in China from various countries. In terms of actual number, 2116 applications were from China, 651 were from the United States and 432 from Germany, India and Switzerland combined (accounting for $11.3 \%$ of the total).

Table 9 shows that coastal provinces and cities have stronger capabilities in the pharmaceutical industry than the western and inland regions.

\subsubsection{Botanical Drug Patents}

A botanical drug is one of the most important types of pharmaceutical products. Relevant patents are also key assets for such technology. In Table 10, it is clear that as of 12 December 2013, China has more than 100,000 patent applications, far greater than any other countries, and the amount of granted patents is 38,191 . Among those Asian countries, the number of Japanese patent applications is the highest (more than 20,000), and South Korea's amount is in the second position, while India has over 200 applications.

As shown in Fig. 15, the total number of Patent Cooperation Treaty (PCT) applications from the United States is the largest, nearly three times that of Japan, more than four times that of Korea and nearly seven times that of China. However, the total application amount in the last 5 years of the United States is still higher than that of other countries, but the amounts have risen sharply for Korea, Japan and China. 


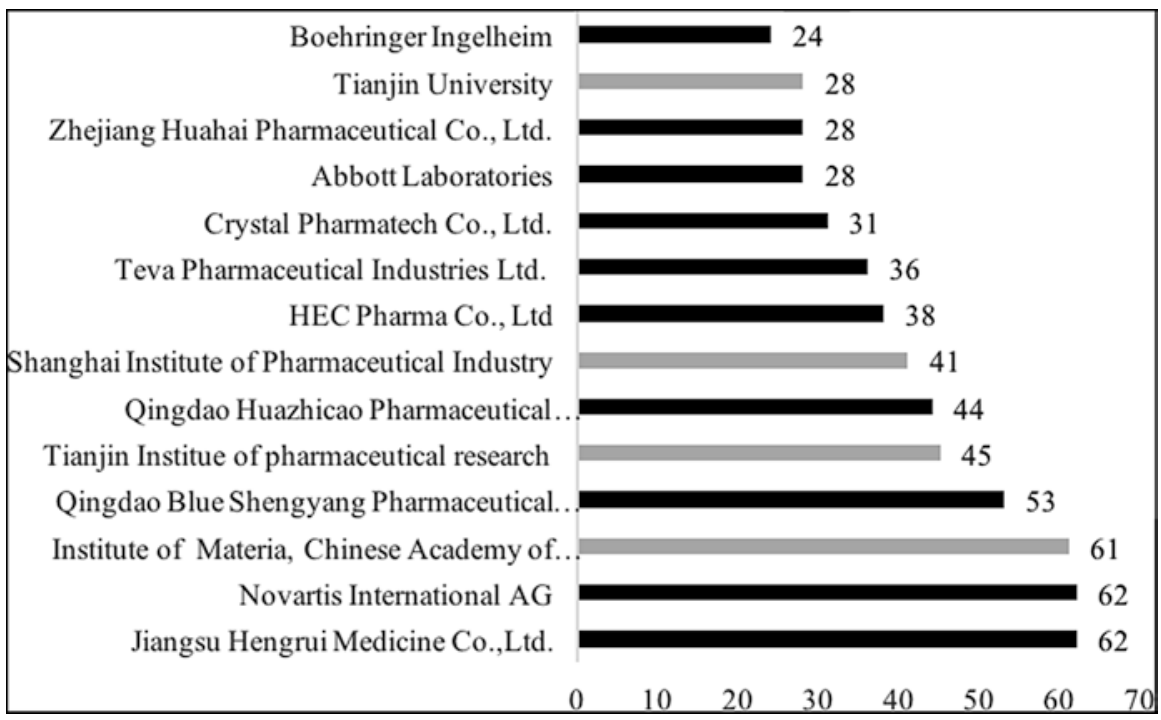

Fig. 13 Top 15 polymorphic drug patent applicants in China (1985-2015) (Wang et al. 2017)

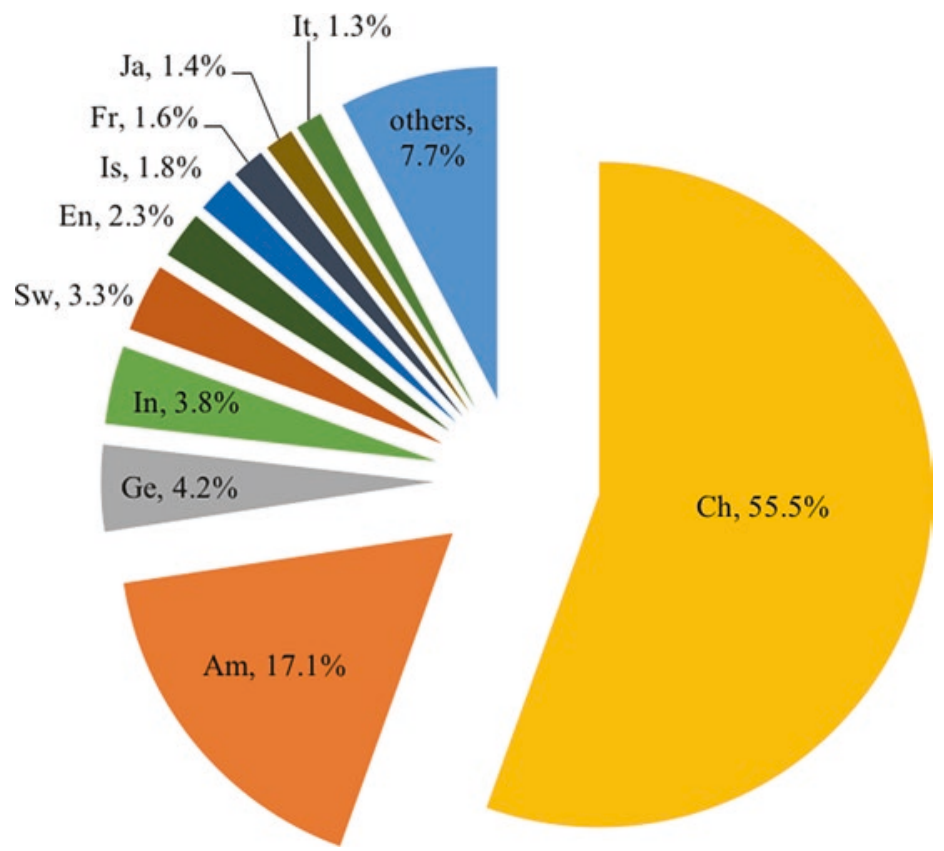

Fig. 14 Polymorphic drug patent applicants in China from various countries (1985-2015) (Wang et al. 2017) 
Table 9 Polymorphic drug patent applications in China from various provinces and cities (19852015) (Wang et al. 2017)

\begin{tabular}{l|l|l|l|l|l}
\hline Regions & Quantity & Regions & Quantity & Regions & Quantity \\
\hline $\begin{array}{l}\text { Jiangsu } \\
\text { Province }\end{array}$ & 365 & Anhui Province & 30 & Hunan Province & 12 \\
\hline $\begin{array}{l}\text { Shandong } \\
\text { Province }\end{array}$ & 247 & Fujian Province & 30 & Henan Province & 12 \\
\hline Beijing & 239 & $\begin{array}{l}\text { Liaoning } \\
\text { Province }\end{array}$ & 24 & Shanxi Province & 9 \\
\hline $\begin{array}{l}\text { Shanghai } \\
\text { Tianjin }\end{array}$ & 238 & Jilin Province & 22 & $\begin{array}{l}\text { Guangxi Zhuang } \\
\text { Autonomous Region }\end{array}$ & 6 \\
\hline $\begin{array}{l}\text { Zhejiang } \\
\text { Province }\end{array}$ & 195 & $\begin{array}{l}\text { Shaanxi } \\
\text { Province }\end{array}$ & 20 & $\begin{array}{l}\text { Inner Mongolia } \\
\text { Autonomous Region }\end{array}$ & 1 \\
\hline $\begin{array}{l}\text { Guangdong } \\
\text { Province }\end{array}$ & 132 & Yunnan Province & 19 & Guizhou Province & 1 \\
\hline $\begin{array}{l}\text { Sichuan } \\
\text { Province }\end{array}$ & 100 & Jiangxi Province & 17 & Gansu province & 1 \\
\hline $\begin{array}{l}\text { Hebei Province } \\
\text { Chongqing }\end{array}$ & 66 & Hainan Province & 17 & $\begin{array}{l}\text { Ningxia Hui } \\
\text { Autonomous Region }\end{array}$ & 1 \\
\hline
\end{tabular}

Table 10 The amount of botanical drug patent applications in various countries (Zhang and $\mathrm{Xu}$ 2014)

\begin{tabular}{l|c}
\hline Country & $\begin{array}{l}\text { The amount of patent } \\
\text { applications }\end{array}$ \\
\hline China & 105,751 \\
\hline Japan & 22,184 \\
\hline United & 15,573 \\
States & 8468 \\
\hline Korea & 4320 \\
\hline Germany & 223 \\
\hline India & \\
\hline
\end{tabular}

Note: The data is from Espacenet Worldwide database as of 12 Dec 2013

Chinese applicants filed 105,751 applications and got 38,191 grants worldwide. Japanese applicants applied for patents in China more than in other countries, but the total number of applications is only 552 and less than 250 grants, followed by the United States (see Fig. 16). Japanese applicants from cosmetics accounted for about $10 \%$. The figure for Korean and American applicants is about 8\%, while almost all of the applicants from Germany and India have little involvement with cosmetics (Zhang and $\mathrm{Xu} 2014$ ).

According to Table 11, traditional Chinese medicine enterprises already have a large number of botanical drug patent applications and granted patents in China, while their foreign applications have just started. 


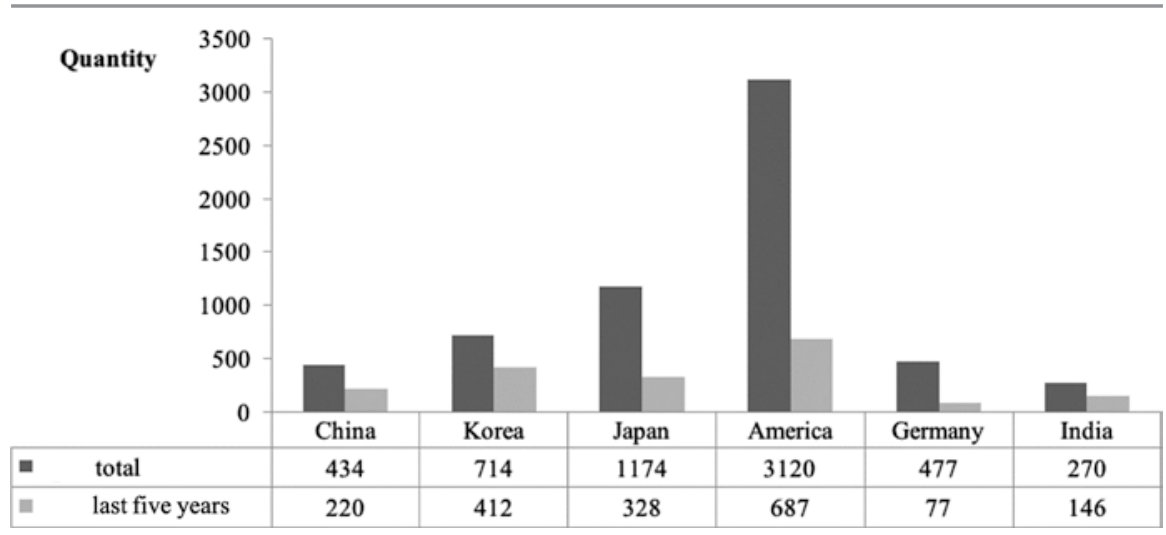

Fig. 15 The amount of botanical drug patent applications filed through PCT from various countries (2009-2013) (Zhang and Xu 2014)

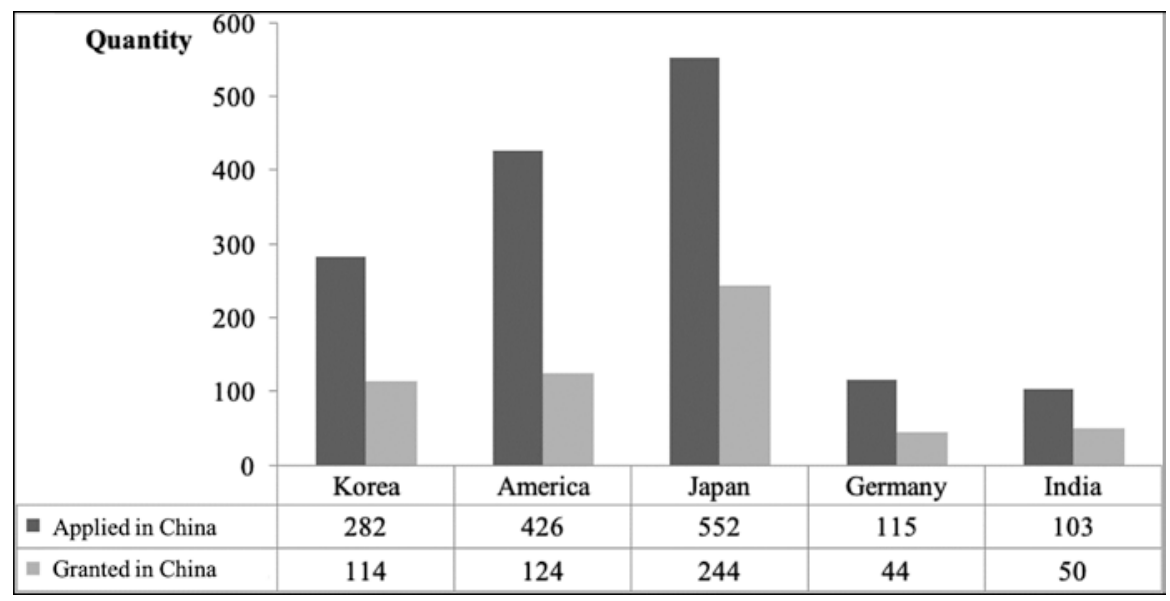

Fig. 16 The amount of Chinese botanical drug patent applications and granted patents by Countries (2009-2013) (Zhang and Xu 2014)

\section{Comparison of the Pharmaceutical Industries Between China and India}

\subsection{Similarities and Differences}

It will be beneficial to compare the development of pharmaceutical industries of China and India. The two countries are similar in many aspects, such as most condensed population (altogether, $40 \%$ of the population in the world), developing mode similar from an agricultural-based economy to gradually industrial economies, and most importantly, both are in the fastest growth rate in economic performance. Moreover, the two countries also face serious problems of uneven 
Table 11 The botanical drug patent applications granted patents and PCT applications in top 10 traditional Chinese medicine enterprises in China (2010) (Zhang and Xu 2014)

\begin{tabular}{l|l|l|l}
\hline Company name & $\begin{array}{l}\text { Patent } \\
\text { applications }\end{array}$ & $\begin{array}{l}\text { Granted } \\
\text { patents }\end{array}$ & PCT applications \\
\hline Yunnan Baiyao & 53 & 36 & 0 \\
\hline Jilin Aodong & 44 & 26 & 0 \\
\hline Tasly & 721 & 472 & 45 \\
\hline Kangmei Pharmaceutical & 30 & 4 & 0 \\
\hline Kanion Pharmaceutical & 110 & 103 & 0 \\
\hline Tong Ren Tang & 102 & 57 & 3 \\
\hline Dong-E-E-Jiao & 20 & 8 & 1 \\
\hline Tai Chi Group & 53 & 38 & 1 \\
\hline $\begin{array}{l}\text { Zhongheng Group Guangxi Wuzhou } \\
\text { pharmaceutical }\end{array}$ & 25 & 10 & 0 \\
\hline Conba & 31 & 17 & 1
\end{tabular}

development level between regions and populations and mounting challenges in environmental deterioration.

On the one hand, in terms of economic scale, both went through economic reforms in their own ways during 1970s and 1980s. Based on data from World Bank, the GDP of China increased from US\$59.2 billion in 1960s to US\$10.87 trillion in 2015, while the GDP of India increased from US\$37.7 billion in 1960s to US\$ 2.07 trillion in 2015. On the other hand, in terms of ways of economic progress, there were indeed profound differences.

International scholars usually believe there are similarities in the two countries. For instance, Pye et al. (2006) did an all-round investigation from different perspective and considered strong similarities between them. As for Chinese scholars, however, differences were more emphasized. Zhao (2008) specially investigated the economic development modes of the two countries, suggested that it would be difficult to tell which way would be better than the other.

There are many contrasts between China and Indian in pharmaceutical industries. On the specific nature towards local pharmaceutical market, Huang and Khanna (2003) suggested that foreign direct investment (FDI), rather than local private firms, could be considered as major driving force for local economy in China, while local firms were strongly protected in India, and the local banking system and capital market were more appropriate for local firms in India as well. Farrell et al. (2004) clarified that the major growth power in China was from manufacturing sectors, accompanied by higher rate of bank savings ${ }^{8}$ larger scale investment on infrastructure and inward overseas capitals, while Indian free market mechanism might be more promising, although the country was slow in economic reform (which also implies less active in IP protections in pharmaceutical sectors) and infrastructure development. Quan (2006) and Li (2006) considered that there was much less government intervention in the market development in Indian case;

\footnotetext{
${ }^{8}$ In China, household saving rate is generally high. If compared with GDP volume, the household saving rate in China is about $9 \%$ on average between 1998 and 2015.
} 
therefore, the intellectual and financial resource, particularly technology resource in computer software industries could be developed "naturally", whereas there would be stronger government intervention over manufacturing capacities in both technology and production in China; in such case, dynamic and active market players might be restricted. Shi (2007) further suggested that the economic growth mode was consumption-based in India, with less intervention from local government, while such growth could be investment-based in China, where government might play an important role in it.

\subsection{India as Patent Maverick vs. China as Patent Taker}

Agreement on Trade-Related Aspects of Intellectual Property Rights (TRIPS) under World Trade Organization (WTO) policy framework is often considered highly beneficial for industrialized nations (Nayyar 1992), especially in terms of pharmaceutical sectors (Marjit 1994). However, India has managed to go its own way on patent although it became WTO member in 1995. For example, on the issue whether biotechnology could be patented, India insisted on its interests (Rao 2002, Kumar 1998) and decided in the Patents Act of 1970 not to protect medicine, only production method of medicine, until the amended Patents Act of 2005. This means there was quite a long time for Indian companies to legally imitate medicine patented in other countries.

Even after 2005, the newly added section 3(d) of the Patents Act does not protect minor modification, in order to prevent evergreening of patents: "the mere discovery of a new form of a known substance which does not result in the enhancement of the known efficacy of that substance or the mere discovery of any new property or new use for a known substance or of the mere use of a known process, machine or apparatus unless such known process results in a new product or employs at least one new reactant". Section 3(d) allows the generic companies to continue operating with a breathing space (see chapters "Historical Evolution of India's Patent Regime and Its Impact on Innovation in the Indian Pharmaceutical Industry" and "The Challenges, Opportunities and Performance of the Indian Pharmaceutical Industry Post-TRIPS" for details). In contrast, China has been a faithful taker of TRIPS Agreement, never challenged or even questioned patent protection of pharmaceutical inventions.

\subsection{Summary}

A comparison of the developmental similarities and differences between China and India can be summarized as follows (see Table 12).

Based on items contrasted in Table 12 and other related analysis, the strength of China's pharmaceutical industry mainly includes a strong industry base for APIs, low labour costs and well-established domestic infrastructure. The weakness, on the other hand, includes poor competitiveness in the domestic pharmaceutical market 
Table 12 A comparison of pharmaceutical industry development in China and India (Wang 2013)

\begin{tabular}{|c|c|c|}
\hline Criterion & Similarities & Differences \\
\hline \multirow[t]{4}{*}{ Macroeconomy } & $\begin{array}{l}\text { Populous developing countries, low } \\
\text { per capita GDP }\end{array}$ & \multirow[t]{4}{*}{-} \\
\hline & $\begin{array}{l}\text { Experienced rapid economic growth } \\
\text { over the past three decades }\end{array}$ & \\
\hline & $\begin{array}{l}\text { Low level of medical care and } \\
\text { individual medicine consumption }\end{array}$ & \\
\hline & $\begin{array}{l}\text { Less sound social security and } \\
\text { medical insurance systems }\end{array}$ & \\
\hline \multirow[t]{3}{*}{ Market size } & \multirow{3}{*}{$\begin{array}{l}\text { Except for the population and the } \\
\text { consumption of medicines, the } \\
\text { pharmaceutical market fundamentals } \\
\text { in the two countries are very similar }\end{array}$} & $\begin{array}{l}\text { China's pharmaceutical market is } \\
\text { three times that of India }\end{array}$ \\
\hline & & $\begin{array}{l}\text { China's population is } 1.3 \text { times } \\
\text { that of India }\end{array}$ \\
\hline & & $\begin{array}{l}\text { China's per capita consumption of } \\
\text { medicines is } 2.3 \text { times that of } \\
\text { India }\end{array}$ \\
\hline \multirow[t]{4}{*}{$\begin{array}{l}\text { Industry } \\
\text { competition }\end{array}$} & Low market concentration & $\begin{array}{l}\text { China's top ten pharmaceutical } \\
\text { companies with total market share } \\
\text { of } 15-18 \% \text {, while India's has been } \\
\text { about } 35 \% \text { since } 1999\end{array}$ \\
\hline & Excessive competition & \multirow{3}{*}{$\begin{array}{l}\text { The polarization of the } \\
\text { pharmaceutical companies between } \\
\text { large and small is more significant } \\
\text { in India }\end{array}$} \\
\hline & $\begin{array}{l}\text { Low R\&D investment in } \\
\text { pharmaceutical companies }\end{array}$ & \\
\hline & Low-level repeated competition & \\
\hline \multirow[t]{2}{*}{ Industry policy } & \multirow{2}{*}{$\begin{array}{l}\text { Since India's new Patents Act came } \\
\text { into force in 2005, the patent systems } \\
\text { in the two countries have been } \\
\text { gradually harmonized and in line } \\
\text { with international standards }\end{array}$} & $\begin{array}{l}\text { China's Patent Law met } \\
\text { international standards in } 1993 \text { by } \\
\text { extending the object of patent } \\
\text { protection from method to products }\end{array}$ \\
\hline & & $\begin{array}{l}\text { Between } 1970 \text { and } 2005 \text {, India } \\
\text { only granted patents for drug } \\
\text { production process, not for the } \\
\text { compound itself }\end{array}$ \\
\hline Infrastructure & - & $\begin{array}{l}\text { India is less developed than China } \\
\text { in industrial facilities. For example, } \\
\text { India's electricity shortfall was } \\
10.3 \% \text { and reached a peak of } \\
12.9 \% \text { in } 2011\end{array}$ \\
\hline
\end{tabular}

compared with multinational pharmaceutical firms, comparatively low-level R\&D and professional techniques in advanced medicine production and especially low added value in international market.

Li and Huang (2007) considered that Chinese pharmaceutical companies' weak position in market competition can be attributed to inadequate innovation, restricted financial capital resource and less capable market control. Based on analysis via SWOT methodology ${ }^{9}$ over Chinese and Indian drug companies, Li and Huang

${ }^{9} \mathrm{SWOT}$ is the typical methodology applies to strategic management cases, with four factor-based framework, namely, Strengths and Weakness (SWs, considered as inner factors), Opportunities and Threats (OTs, considered as environmental factors). 
found that Indian firms were more competitive in newly developed medicine in international market, quality certification and technical talents. In another comparative study, Zhang and Zhang (2009) found that Chinese firms in pharmaceutical sectors are weak in market share, earning, innovation and, most importantly, IP resource. Cai and Xiao (2013) found that Indian pharmaceutical outsourcing (CRO) sector perform overall better than Chinese, especially in terms of labour, technologies and management skills, while Chinese CRO sector appears to have better policy environment and market size. Mao and Zhang (2011) have investigated Indian pharmaceutical industries primarily from a number of key dimensions, such as local IP policy system, basic research system, national drug policies and human resource training system, and concluded that those systems and relevant dimensions, which should be understood as Pharmaceutical Sectoral Innovation System, could explain the successful development of the pharmaceutical industries in India.

There are other quantitative studies on Chinese and Indian pharmaceutical industries. For example, Li (2008) found that although the product innovation was comparatively weak, the industry did have comparative advantage in terms of market size and policy support in China. Liu and Yu (2010) found Chinese industry falling far behind Indian firms in internationalization. Xiao (2015) further indicated Chinese industry might have comparative advantage only in production scale and market growth and might be falling behind in $\mathrm{R} \& \mathrm{D}$ and internationalization. As is emphasized in chapter "The Challenges, Opportunities and Performance of the Indian Pharmaceutical Industry Post-TRIPS", though major Indian companies are all producers of generic medicines, they continue to invest sizeable share of their sales turnover in R\&D. It may imply that the innovation and development of Indian pharmaceutical industry might be faster.

\section{Conclusion}

The Chinese pharmaceutical industry has been developing fast, in terms of increasing market size and revenue volumes, and upgraded technologies, along with the gradual opening up of the industries. Although there is a huge increase in the number of patented drugs granted to Chinese pharmaceutical companies, patents have made low contribution to the industrial values, and IP held by Chinese firms is less competitive compared with foreign companies. Most of the pharmaceutical enterprises in China still focus on generic drugs.

The scale of Chinese pharmaceutical companies is small, and the market concentration is low. Therefore, local pharmaceutical companies with higher R\&D input are generally less profitable, which prevents Chinese companies from conducting effective R\&D and leads them to develop in thinner profit margin market and in production of patent-expired drugs. Pharmaceutical R\&D or related research is often conducted by research institutes or universities, rather than by companies in China.

Market regulation of the pharmaceutical industry in China is relatively strict, especially market entry and price control. Indeed, this may increasingly create more 
monopolistic buying position for state-owned hospitals and decrease or weaken the negotiating power of pharma enterprises.

India is well known as patent maverick, whereas China as a naïve patent taker, especially in pharma invention. With Indian Patents Act utilizing the leeway left by the TRIPS Agreement to better suit its national interests and developmental needs, India's pharma industry is poised to further outperform its Chinese counterpart.

\section{References}

Cai, J. (2009). Research on the key influencing factors of innovation ability of pharmaceuticals industry in China. Shanghai Journal of Economics, 11, 14-20. (in Chinese).

Cai, W., \& Xiao, L. (2013). 2013 Comparative study on pharmaceutical outsourcing sectors between China and India. Health Economies, 12, 22-24. (in Chinese).

Chen, J. (2014). On perfection of regulation system of patent drugs and generic drugs in ChinaFrom the perspective of American experience. Dissertation, East China University of Political and Law. (in Chinese).

Chen, X., \& Liu, Y. (2006). Discussion on the problem of overpriced patent drugs. Price: Theory \& Practice, 26(7), 27-28. (in Chinese).

Chen, Z., \& Wang, J. (2017). The impact of China's pharmaceutical industry policy on the innovation and development of pharmaceutical enterprises. Management and Administration, 8, 40-42. (in Chinese).

China industrial and economic information. Available via www.chyxx.com/industry/yiyao/. Accessed 14 Aug 2018.

China industrial economy and information. Available via http://www.chyxx.com/ industry/201708/549493.html. Accessed 14 Aug 2018.

Fang, L. (2013). Research on risk management of generic drugs on patent infringement. Dissertation, Huazhong University of Science \& Technology. (in Chinese).

Farrell, D., Khanna, T., Sinha, J., et al. (2004). China and India: The race to growth. The McKinsey Quarterly, 110-111.

Huang, Y., \& Khanna, T. (2003). Can India overtake China? Foreign Policy, 7-8.

IMS. The Phamia report 2008.

IMS. The global use of medicines: Outlook through 2015.

Ji, S., \& Zhou, X. (2010). R\&D efficiency investigation on Chinese medicine manufacturing sectors - A HMB productivity index based empirical study. Financial Review (Journal of Zhejiang Financial University), 154(6), 10-15. (in Chinese).

Jiang, L., Guo, W., Hua, X., et al. (2017). Chinese patent medicine market analysis under the background of national drug price negotiation. World Clinical Drugs, 38(5), S31-S34. (in Chinese).

Jin, S., Hu, Y., \& Wang, Y. (2007). Comparative analysis of pharmaceutical industry in China, Europe and the US - Structure, behavior and performance. Chinese Journal of Pharmaceuticals, 38(7), 79-84. (in Chinese).

Kumar, N. (1998). India, Paris convention and TRIPS. Economic \& Political Weekly, 33(36-37), 2334-2335.

Li, M. (2006). Different development route: Analysis on the case of China and India. Journal of HuBei Engineering Institute, 26(4), 28-31. (in Chinese).

Li, F. (2008). An empirical study on practical competitiveness in Chinese pharmaceutical industries. Science and Information Development and Economies, 18(26), 83-85. (in Chinese).

Li, J., \& Huang, T. (2007). Study over raising competitiveness in Chinese pharmaceutical industries. China Pharma, 16(18), 16-17. (in Chinese).

Li, L., \& Lv, Y. (2002). Review of hot issues in the field of public health. China Public Health, 18(11), 1281-1283. (in Chinese). 
Li, X., \& Yang, P. (2016). Development status and advantages of the Chinese biopharmaceutical industry. China Pharmaceuticals, 25(8), 8-9. (in Chinese).

Liu, C. (2010). Research on drug market exclusion and restrictive competition after patent expiration. Dissertation, Dongbei University of Finance and Economics. (in Chinese).

Liu, X. (2012). Monopsony, pricing and $R \& D$ input in China's pharmaceutical industry. Dissertation, Shandong University. (in Chinese).

Liu, Y., \& Wang, H. (2007). Develop medical technology and build a pharmaceutical powerhouse - International comparison of Chinese Medical Science and Technology and Industrial Competitiveness, Beijing 123-138 (in Chinese).

Liu, Y., \& Yu, Z. (2010). Internationalization strategies of Indian pharmaceutical firms and their implication to Chinese pharmaceutical sectors. China Professional Pharmacist, 07(11), 41-44. (in Chinese).

Mao, N., \& Zhang, S. (2011). Evolution of innovation system in Indian pharmaceutical industries - Experiences and implications. Modern Management Science, 6, 68-70. (in Chinese).

Marjit, S. (1994). Trade related IP rights and GATT: A theoretical evaluation. Economic \& Political Weekly, 29(53), 3327-3332.

Meng, F. (2017). Research on the influence of FDI to the structure of Chinese pharmaceutical manufacturing industry market - Based on the empirical analysis of market concentration. Dissertation, Shandong University. (in Chinese).

$\mathrm{Mu}, \mathrm{R} .$, \& Cai, C. (2001). Evaluation on international market competitiveness of Chinese pharmaceutical manufacturing industries. Science and Research Management, 22(2), 127-135. (in Chinese).

National Bureau of Disease Prevention and Control of the National Health Planning Commission. (2016). An overview of national legal infectious diseases in 2015. http://www.nhfpc.gov.cn/jkj/ s3578/201602/b9217ba14e17452aad9e45a5bcce6b65.shtml. Accessed 21 Oct 2017.

Nayyar, D. (1992). IP rights and LDCs: Some strategic issues. Economic \& Political Weekly, 27(6), 271-274.

PAC. (2010). Study of China's original drug and generic drug - Price differences and market share status report.

Publicity Department of the National Health Planning Commission. (2015). The report of Chinese resident nutrition and chronic disease status. Available via http://www.nhfpc.gov.cn/xcs/s3574 /201506/6b4c0f873c174ace9f57f11fd4f6f8d9.shtml. Accessed 21 Oct 2017.

Pye, L. W., et al. (2006). Asia's Giants: Comparing China and India. Foreign Affairs, 5, 177.

Quan, H. (2006). The notion of "World factory" and "World office" - Comparison of Chinese and Indian economic development model. Scientific Decision, 12, 34-36. (in Chinese).

Rao, C. N. (2002). Patents for biotechnology inventions in TRIPs. Economic \& Political Weekly, $37(22), 2126-2129$.

Shi, L. (2007). Dragon and elephant: Comparative study on the different development models between China and India. China Statistics Journal, 1, 22-23. (in Chinese).

Sun, C. (2001). Use new formula for calculating addition rate of drugs to control pharmacy drug administration. Medical Journal of the Chinese People's Armed Police Forces, 12(2), 101-102. (in Chinese).

Sun, Y. (2016). China's bio-pharmaceutical industry in the past, present and future. Heilongjiang Science and Technology Information, 34, 72-72. (in Chinese).

Sun, Q., et al. (2008). Pharmaceutical policy in China. Health Affairs, 27(4), 1042-1050.

Wang, C. (2008). Innovation needs encouragement policies for the creation of major new drugs. Venture Capital, $O(1), 26-28$. (in Chinese).

Wang, J. (2012). The research on the pricing mechanism of non-patent drugs. Dissertation, Nanjing University (in Chinese).

Wang, J. (2013). The study on investment of pharmaceutical companies in the context of global patent drugs expiration tide. Dissertation, Shanghai Jiao Tong University (in Chinese).

Wang, X., Xu, Q., \& Zhao, C. (2017). Research progress of pharmaceutical polymorphs in China based on patents analysis. Chinese Journal of New Drugs, 26(8), 845-850. (in Chinese).

Wei, J. (2009). Chinese pharmaceutical development and reform. Beijing, 189-190. (in Chinese). 
William, L. (2016). Pharm exec's top 50 companies. http://www.pharmexec.com/2016-pharmexec-502016. Accessed 21 Oct 2017.

$\mathrm{Wu}$, J. (2006). Research on China pharmaceutical industry policy - Based on the perspective of background, behavior and performance. Dissertation, Fudan University (in Chinese).

Xiao, Y. (2015). A comparative study on pharmaceutical industries between China and India. Journal of East China Polytechnic University (Social Science Edition), 30(5), 49-55. (in Chinese).

Xiao, Y. (2017). Study on patent link during generic drug registration - Suggestions for revision towards the "Provisions for drug registration" 18, 19 amendments based on tripartite interests. China Invention \& Patent, 6, 70-74. (in Chinese).

Yao, J. (2011). Pharmaceutical patents from a global perspective: From profit distribution to benefit creation. Beijing. (in Chinese).

Yu, G. (2008). Research and development issues of new drugs in our country and its outlet. Innovation Science and Technology, 1, 20-21. (in Chinese).

Yuan, K. (2005). Price increasing is only a temporary solution. China Contemporary Medicine, $0(7), 88-88$. (in Chinese).

Zhang, Q. (2009). Empirical study on the competitive advantages of Chinese pharmaceutical industries and their evolution. Explore of Economic Issues, 6, 43-48. (in Chinese).

Zhang, X., \& Xu, J. (2014). Comparative study of patent application situation for herbal drugs in different countries and its revelation of enterprises in china. Science and Technology Management Research, 16, 156-161. (in Chinese).

Zhang, X., \& Zhang, C. (2009). Self-owned IPs on pharma and competitiveness of pharmaceutical companies. China Pharma, 18(6), 14-15. (in Chinese).

Zhang, Y., Liu, Q., \& Xu, Y. (2011). R\&D efficiency and its influencing factors in Chinese pharmaceutical industries. China Science \& Technology Forum, 1, 70-74. (in Chinese).

Zhang, H., Ma, Q., \& Deng, S. (2016). Novelty of polymorphic drug patents. Chinese Journal of New Drugs, 25(5), 490. (in Chinese).

Zhao, J. (2008). Rational thinking of comparison of Chinese and Indian economies. South Asian Research Quarterly, 3, 32-36. (in Chinese).

Open Access This chapter is licensed under the terms of the Creative Commons Attribution 4.0 International License (http://creativecommons.org/licenses/by/4.0/), which permits use, sharing, adaptation, distribution and reproduction in any medium or format, as long as you give appropriate credit to the original author(s) and the source, provide a link to the Creative Commons license and indicate if changes were made.

The images or other third party material in this chapter are included in the chapter's Creative Commons license, unless indicated otherwise in a credit line to the material. If material is not included in the chapter's Creative Commons license and your intended use is not permitted by statutory regulation or exceeds the permitted use, you will need to obtain permission directly from the copyright holder.

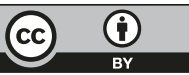

